Notre Dame Law School

NDLScholarship

Journal Articles

Publications

1979

\title{
Per Se Illegality of Concerted Refusals to Deal: A Rule Ripe for Reexamination
}

Joseph P. Bauer

Notre Dame Law School, jbauer@nd.edu

Follow this and additional works at: https://scholarship.law.nd.edu/law_faculty_scholarship

Part of the Antitrust and Trade Regulation Commons

\section{Recommended Citation}

Joseph P. Bauer, Per Se Illegality of Concerted Refusals to Deal: A Rule Ripe for Reexamination, 79 Colum L. Rev. 685 (1979).

Available at: https://scholarship.law.nd.edu/law_faculty_scholarship/397

This Article is brought to you for free and open access by the Publications at NDLScholarship. It has been accepted for inclusion in Journal Articles by an authorized administrator of NDLScholarship. For more information, please contact lawdr@nd.edu. 


\title{
Per Se Illegality of Concerted Refusals to Deal:
}

\section{A Rule Ripe for Reexamination}

\author{
Joseph P. Bauer *
}

Section 1 of the Sherman Act ${ }^{1}$ proscribes "[e]very contract, combination ... or conspiracy, in restraint of trade." Early Supreme Court cases interpreting this provision held that it required a determination by the trier of fact of the "reasonableness" of the challenged conduct in each case-an approach which caine to be known as the "rule of reason." 2 In subsequent cases, however, the Court has held that certain conduct is unreasonable per se. ${ }^{3}$ That is, once a court has determined that such conduct has taken place, it is foreclosed from undertaking an inquiry into the reasonableness of that conduct. ${ }^{4}$ One form of activity that has been declared unreasonable per se is the group boycott, or concerted refusal to deal. ${ }^{5}$ Recently, this particular doctrine has been the subject of much concern and criticism by lower federal courts $^{6}$ and commentators. ${ }^{7}$ Although many courts adhere unquestioningly

* Associate Professor of Law, Notre Dame University. B.A. 1965, University of Pennsylvamia; J.D. 1969, Harvard University.

1. 15 U.S.C. $\$ 1$ (1976).

2. See Chicago Bd. of Trade v. United States, 246 U.S. 231 (1918); United States v. American Tobacco Co., 221 U.S. 106 (1911); Standard Oil Co. v. United States, 221 U.S. 1 (1911).

3. In addition to concerted refusais to deal, see note 5 infra, other forms of conduct that the Suprene Court has held to be unreasonable per se include: horizontal price restraints, Kiefer-Stewart Co. v. Joseph E. Seagram \& Sons, 340 U.S. 211 (1951); United States v. Socony-Vacuum Oil Co., 310 U.S. 150 (1940); United States v. Trenton Potteries Co., 273 U.S. 392 (1927); vertical price restraints, Albrecht v. Herald Co., 390 U.S. 145 (1968); United States v. Parke, Davis \& Co., 362 U.S. 29 (1960); horizontal territorial and customer restraints, United States v. Topco Assocs., 405 U.S. 596 (1972); vertical territorial and customer restraints, United States v. Arnold, Schwinn \& Co., 388 U.S. 365 (1967), overruled by Continental T.V., Inc. v. GTE Sylvania Inc., 433 U.S. 36 (1977); and tying arrangements, Northern Pac. Ry. v. United States, 356 U.S. 1 (1958).

4. Thus, a court's initial task is to characterize the conduct. If the actions fit within the definition of the universally proscribed conduct, they are deemed unlawful without further investigation. If they do not, the court will evaluate the conduct under the rule of reason. See notes $43-49$ and accompanying text infra.

5. See Klor's, Inc. v. Broadway-Hale Stores, Inc., 359 U.S. 207 (1959). See also notes 12-42 and accompanying text infra. As the terms are used in this Article, a group boycott or concerted refusal to deal is an agreement by two or nore parties that at least one party thereto will undertake either to threaten or in fact not to buy from, sell to, or in some other respect deal with some person not a party to the agreement. "Person" is used here in the same sense as it is defined in $\$ 8$ of the Sherman Act, 15 U.S.C. $\$ 7$ (1976), to include corporations and associations as well as living individuals. The refusal to deal includes within its scope not only the absolute refusal to buy or sell, but also the refusal to deal except at higher prices or on more onerous terms. Professor Sullivan argues that the term "concerted refusal to deal" niay be either too broad or too narrow to describe the conduct covered by the per se rule. He therefore prefers the term "boycott," although it adinittedly has emotional content. L. Sullivan, HaNDBook of tHe LAW of ANTrrRusr 231-32 (1977). This Article will adopt the more common practice of using these two terms interchangeably.

6. See, e.g., cases cited in notes $46-48$ infra.

7. See Horsley, Per Se Illegality and Concerted Refusals to Deal, 13 B.C. Indus. \& CoM. L. Rev. 484 (1972); McCormick, Group Boycotts-Per Se or Not Per Se, That is the Question, 7 Seron Hald L. Rev. 703 (1976); Woolley, Is a Boycott a Per Se Violation of the Antitrust Laws?, 27 Rutgers L. Rev. 773 (1974); Comment, Boycott: A Specific Definition Linits the Applicability of a Per Se Rule, 71 Nw. U.L. Rev. 818 (1977); Comment, A Reexamination of the Boycott Per Se Rule in Antitrust Law, 48 TEMP. L.Q. 126 (1974); 42 U. CoLO. L. Rev. 467 (1971). 
to this per se rule, others have either found the doctrine inapplicable to the facts at bar or resorted to limiting a rule upon which the Supreme Court has placed no limitations. As a result, the present state of the law reflects much confusion.

Recently, in Continental T.V., Inc. v. GTE Sylvania Inc.8 the Supreme Court took a step unprecedented in at least the last sixty-five years of antitrust jurisprudence-it overturned a per se rule which had outlawed all vertical territorial and customer restraints in which the buyer acquired title to the goods, and reinstated a rule of reason analysis for this type of conduct. One of the rationales given by the Sylvania Court for rejecting a per se approacli was the frequent criticisin the old rule-the Schwinn doctrine ${ }^{9}$ - had received both in the hiterature and in the lower courts. ${ }^{10}$

The Supreme Court has repeatedly indicated its adherence to the per se rule respecting group boycotts. ${ }^{11}$ Yet, in view of the recent treatment this rule lias received in the courts and in the law journals, the Sylvania decision gives reason to believe that this particular doctrine miglt also be the subject of reexamination and possible modification.

This Article will first explore the developinent of the rule holding concerted refusals to deal unreasonable per se and the justification for such an approach. It will then consider why many courts and commentators are dissatisfied with the present approach and will discuss low lower federal courts have avoided using it. Finally, the Article suggests that criticism of the per se rule is justified, and proposes a partial return to a rule of reason analysis, with carefully defined criteria for testing legahity and a more narrowly circumscribed per se rule.

\section{BACKGROUND}

\section{A. Supreme Court Development of the Per Se Rule}

In Montague \& Co. v. Lowry, 12 a 1904 case, the Supreme Court first held that a concerted refusal to deal violates section 1 of the Sherman Act. An association of wholesalers and manufacturers was formed under which manufacturers who sold to nonmembers would be expelled from the association. Several competing nonmember dealers were thereby precluded from purchasing directly from their former suppliers; instead, they were

8. 433 U.S. 36 (1977). See generally Pitofsky, The Sylvania Case: Antitrust Analysis of Non-Price Vertical Restrictions, 78 CoLun. L. Rxv. 1 (1978).

9. United States v. Arnold, Schwinn \& Co., 388 U.S. 365 (1967) (vertical territorial and customer restraints on the sale of goods, where the title to the goods passes to the buyer, aro illegal per se).

10. 433 U.S. at $48 \& \mathrm{nn} .13 \& 14$.

11. See cases cited in note 35 infra.

12. 193 U.S. 38 (1904). Allegations of concerted refusals to deal had been made in two earlier cases, but neither decision was on the merits. Anderson v. United States, 171 U.S. 604 (1898) (restraint held not to violate Sherman Act because effect on commerce was "but indirect and incidental"); Hopkins v. United States, 171 U.S. 578 (1898) (Sherman Act held inapplicable because conduct did not affect interstate commerce). 
forced to buy from the wholesaler-nembers at a greatly increased price. ${ }^{13}$ Although the Court's decision contained almost no indication of the standard that was applied, it held that the "agreement directly affected and restramed interstate commerce" 14 and therefore was unlawful.

Ten years later, in Eastern States Retail Lumber Dealers' Association v. United States, ${ }^{15}$ the Court held another concerted refusal to deal unlawful. A group of retailers had implicitly agreed not to buy froin wholesalers who sold directly to customers. The Court noted that each dealer had the right, acting individually, to choose wliether or not to do business with any particular seller-that is, unilaterally to refuse to deal. It explained that the evil of a group boycott arose from the use of the combined market strength of the group to coerce the wholesaler to conform to the desired conduct. ${ }^{10}$ The Court also noted that the conduct would not have been saved even if the parties had been seeking to promote either the welfare of their industry or what they perceived to be the public welfare; the Sherman Act, it asserted, simply does not permit private traders to use their joint buying and selling power to make this judgment. ${ }^{17}$

The first suggestion that a per se rule might apply to group boycotts ${ }^{18}$ appeared in Paramount Famous Lasky Corp. v. United States. ${ }^{19}$ In that case, ten producer-distributors controlling a large portion of the motion picture business agreed to require of all exhibitors a standard exhibition contract, which included a provision for arbitration of any disputes and required an exhibitor to post a security deposit if it refused to enter into arbitration or later refused to comply with an arbitration award. This refusal of an exhibitor in a dispute with any one producer-distributor resulted in a suspension of service froin all ten. In effect, the joint market power of the producer-distributors-the ability to cut off an exhibitor from the supply of the majority of motion picture films-was used to coerce the exhibitors to adhere to the contractual provisions with each individual distributor.

In response to the allegations that this arrangement violated section 1 of the Sherman Act, the defendants asserted that the agreements were reasonable in view of the needs of the industry. These self-help mechanisms, they asserted, were one of the few effective ways for companies to learn about the reliability of buyers. The Supreme Court, applying the rule of

13. Here, the group boycott was a joint refusal to sell to the plaintiffs-an absolute refusal by the manufacturer-members and a conditional refusal (only at dramatically higher prices) by the wholesaler-members.

14. 193 U.S. at 48.

15. 234 U.S. 600 (1914).

16. Id. at 611-12.

17. Id. at 613 .

18. In the period between Eastern States Retail Lumber Dealers' Ass'n and Paramount, the Court passed upon concerted refusals to deal in three cases: Bedford Cut Stone Co. v. Journeymen Stone Cutters' Ass'n, 274 U.S. 37 (1927) (concerted refusals to work by members of labor organizations); Bimderup v. Pathe Exch., Inc., 263 U.S. 291 (1923) (joint refusal by distributors of motion pictures to license exhibitor); Duplex Printing Press Co. v. Deering, 254 U.S. 443 (1921) (secondary boycott by labor organizers).

19. 282 U.S. 30 (1930). 
reason, concluded that the agreements suppressed normal competitive processes and were unlawful. ${ }^{20}$

The decision, however, is more significant for its omissions. Three years earlier the Court, in United States v. Trenton Potteries Co., ${ }^{21}$ lad held that certain kinds of conduct-in that case, price-fixing-were unreasonable per se. The Court in Paramount did not discuss whether the per se rule should be extended to include concerted refusals to deal; its decision, however, is difficult to justify solely under the rule of reason. There was virtually no discussion of the nature of the injury, either to the parties or to the public, of how competition would be affected, or even of why the practice was "unreasonable." In short, the Court was unwilling to consider the potential benefits of these agreements.

Further advances toward institution of the per se rule for concerted refusals to deal were made in Fashion Originators' Guild of America, Inc. v. FTC.22 The defendants, designers and manufacturers of women's garments and the manufacturers of textiles used in the production of these garments, were upset because certain of their competitors, branded "style pirates," were copying their fabrics and clothes without authorization and selling them at a lower price. The defendants, acting tlirougl the Guild, instituted a jomt protective program; the garment manufacturers agreed not to sell to stores that sold a "pirate's" garnents, and the textile manufacturers agreed not to sell to any dress manufacturer which subsequently sold to stores selling "pirate" goods.

The defendants argued that this boycott program was necessary to protect them from unfair business practices-unauthorized copying-for which they had an inadequate remedy under state tort law; therefore, the program was assertedly a reasonable method of joint self-help. The Court declined to weigh these asserted benefits against the costs to competitors and consumers; instead, it suggested that an exanination of the reasonableness of the agreement was irrelevant: "Under these circumstances, ... the reasonableness of the methods pursued by the combination to accomplish its unlawful object is no more material than would be the reasonableness of the prices fixed by unlawful combination." ${ }^{23}$ The Court never explained why it might not be appropriate, at least in some cases, to make the balancing imquiry of the rule of reason when evaluating concerted refusals to deal..$^{24}$

20. Id. at 43 .

21. 273 U.S. 392 (1927).

22. 312 U.S. 457 (1941).

23. Id. at 468. The circumstances to which the Court apparently referred are "[t]he purpose and object of this combination, its potential power, its tendency to monopoly, [and] the coercion it could and did practice upon a rival method of competition ...." Id. at 467. It is arguable that the Court's "per se" rule would not have applied had these circumstances not been present. See also Millinery Creator's Guild, Inc. v. FTC, 312 U.S. 469 (1941).

24. The Court did indicate why the defendants' conduct ran counter to the policy of the Sherman Act: "[I]t narrows the outhets to which garment and textile manufacturers can sell and the sources from which retailers can buy ...; ;it] subjects all retailers and manufacturers 
In Associated Press v. United States, ${ }^{25}$ defendants were newspapers that had organized the preeminent news wire service in the country. The organization had adopted by-laws which restricted dissemination and sales of the gathered news to other association members and gave member newspapers virtual veto power to block membership applications by nonmembers who were potential competitors. In addition to the monopoly-perpetuating characteristics of these practices, which led to a challenge under section 2 of the Sherman Act, the joint refusal to sell news to nonmembers or to allow them to join the organization was challenged by the Government as a group boycott, illegal under section 1 of the Sherman Act. The Court held that the agreement of these competitors to deal with each other, but not with any other competitor, was unlawful. The Court stressed that the agreement made it harder for the outsiders to compete by making it more difficult and expensive for them to gather news, and raised barriers to entry for would-be competitors. ${ }^{26}$ Although the Court found that the defendants' motive in instituting these rules was to prevent competition, it went on to say that even good motives would not have saved this otherwise illegal combination. ${ }^{27}$ Nonetheless, the opinion again failed to use the "per se" language, and it provided no reason why examination of motives and effect should be foreclosed in all cases. ${ }^{28}$

Any doubt as to whether the Supreine Court had adopted a per se rule for group boycotts was erased by the decision in Klor's, Inc. $v$, BroadwayHale Stores, Inc. ${ }^{29}$ Broadway-Hale, a retailer of appliances in San Fran-

who decline to comply with the Guild's program to an organized boycott . . . ; [it] takes away the freedom of action of members by requiring each to reveal to the Guild the intimate details of their individual affairs ....; and [it] has both as its necessary tendency and as its purpose and effect the direct suppression of competition from the sale of unregistered textiles and copied designs ..." 312 U.S. at 465.

25. 326 U.S. 1 (1945).

26. Id. at 9,13 .

27. Id. at 16 n.15.

28. It is arguable that Associated Press does not involve a concerted refusal to deal, but rather imposes a duty on those with control of a unique asset to deal with the public on nondiscriminatory terms. See United States v. Terminal R.R. Ass'n, 224 U.S. 383 (1912). Compare 326 U.S. at 19 (Black, J.) with id. at 25 (Douglas, J., concurring) and id. at 55 (Murphy, J., dissenting). See also Otter Tail Power Co. v. United States, 410 U.S. 366 (1973); Silver v. New York Stock Exch., 373 U.S. 341, 348-49 n.5 (1963); Gamco, Inc. v. Providence Fruit \& Produce Bldg., Inc., 194 F.2d 484, 487-88 (1st Cir.), cert. denied, 344 U.S. 817 (1952); American Fed'n of Tobacco Growers, Inc. v. Neal, 183 F.2d 869 (4th Cir. 1950). Cf. Athletes Foot, Inc. v. Ralph Libonati Co., 445 F. Supp. 35, 50 (D. Del. 1977) (manufacturer of unique tradenarked product, integral to retailer's business, may be under duty to sell). But see L. Sullivan, supra note 5, at 253-55.

29. 359 U.S. 207 (1959).

In the period between the Associated Press and Klor's decisions, in at least four cases dealing with other aspects of the antitrust laws, the Court reiterated the principle that all inquiries into the reasonableness of this conduct were foreclosed. In United States v. Columbia Steel Co., 334 U.S. 495 (1948), the Court for the first time used the term "per se" in connection with group boycotts. Columbia Steel was an action attacking a horizontal merger under $\$ 1$ of the Sherman Act. In the course of a discussion of several kinds of otherwise reasonable restraints which might become unreasonable in light of the intent of the parties, the Court listed some forms of conduct that would be illegal per se: "For example, where a complaint charges that the defendants have engaged in price fixing, or havo concertedly refused to deal with non-members of an association,... then the amount of commerce involved is immaterial because such restraints are illegal per se." Id. at 522-23 (emphasis added). The 
cisco, apparently was disturbed by plaintiff Klors' price-cutting techniques. ${ }^{80}$ It approached several appliance manufacturers who were suppliers to both parties, demanding that they either not sell to Klor's at all or sell to it only at discriminatorily high prices. After these manufacturers acceded to Broadway-Hale's demand, plaintiff sued, charging that their joint refusal to sell to it constituted an illegal group boycott. The defendants asserted that there had been no public injury, since there were hundreds of stores in San Francisco selling the manufacturers' products even after their refusal to sell to plaintiff; they further asserted that their conduct was reasonable, since it had no effect on the price, quality, or quantity of goods available. The Court rejected these arguments, holding that a group boycott would always be condemned, regardless of actual effect:

Group boycotts, or concerted refusals by traders to deal with other traders, have long been held to be in the forbidden category. They have not been saved by allegations that they were reasonable in the specific circumstances .... Even when they operated to lower prices or temporarily to stimulate competition they were banned. ${ }^{31}$

The Court's opinion did point to some of the evils that flowed from this particular restraint: it deprived Klor's of the right to buy the appliances, eventually driving it out of business; it deprived the sellers of the freedom to sell to Klor's (although this was a right they had voluntarily forsaken and could have recaptured any time they chose); and it had the "tendency toward monopoly," because of the possibility of slowly but steadily driving out of business small companies like Klor's. ${ }^{32}$ Yet, the Court still did not indicate why an inquiry into the defendant's motives and the effect of the conduct on competition should always be foreclosed. In short, there was no analysis of why all group boycotts deserve per se treatment. ${ }^{33}$

The next case decided by the Court under the group boycott doctrime was Radiant Burners, Inc. v. Peoples Gas Light \& Coke Co. ${ }^{34}$ The plaintiff,

Court used similar dictum, restating the per se illegality of group boycotts, in a case attacking a horizontal agreement to set maximum resale prices-Kiefer-Stewart Co. v. Joseph $E$. Seagram \& Sons, Inc., 340 U.S. 211, 214 (1951)-and in two cases challenging tying arrangements-Times-Picayune Publishing Co. v. United States, 345 U.S. 594, 625 (1953), and Northern Pac. Ry. v. United States, 356 U.S. 1, 5 (1958).

Notwithstanding these apparently explicit statements, a number of lower courts in tho 1950's took the view that these Supreme Court pronouncements were merely suggestive and continued to deal with boycott cases under the rule of reason. See the cases cited in Handler, Recent Developments in Antitrust Law: 1958-1959, 59 CoLum. L. REv. 843, 862 (1959), and Barber, Refusals to Deal Under the Federal Antitrust Laws, 103 U. PA. L. REv. 847 (1955), See also 70 HaRV. L. REV. 1113 (1957).

30. See note 118 and accompanying text infra.

31. 359 U.S. at 212 (footnotes omitted).

32. In addition, the boycott of Klor's served as a message to other retailers that if thoy were to engage in price-cutting, they would risk being cut off by their supphers. Thus, the boycott had an anticompetitive effect beyond any damage to Klor's itself.

33. See Rahl, Per Se Rules and Boycatts Under the Sherman Act: Some Reflections on the Klor's Case, 45 VA. L. REv. 1165, 1167 (1959).

34. 364 U.S. 656 (1961) (per curiam). 
Radiant, had developed a gas burner for use in commercial and residential heating. In order to assure the safe use of natural gas, a number of gas utilities, gas pipeline companies, and manufacturers of gas appliances had formed an association to test and approve all gas appliances. The utilitymembers agreed that they would not supply natural gas to retail customers who intended to use it in connection witl unapproved appliances. After the association refused plaintiff its seal of approval, Radiant claimed that the standards were set and applied arbitrarily to prevent it from competing with the manufacturer-members. It sued under section 1 of the Sherman Act, asserting that the refusal to certify and the refusal to sell gas to its prospective customers were an unlawful concerted refusal to deal. The Court reversed the trial court's grant of the defendants' motion for summary judgment, holding that the plaintiff was entitled to a trial to attempt to prove its allegations.

In its brief decision, the Court cited Klor's extensively, repeating the principle that concerted refusals to deal are uniformly forbidden. The case, however, presents novel problems which the Court did not adequately address. Up through Klor's there was a cominon factual thread running through the group boycott cases: the courts in each case could reasonably have inferred an intent to injure the third party. Radiant Burners stretches this thread. Presunably, the Court was not saying that the seal must be given, and the gas sold, even if the appliance were defective or dangerous. Rather, the Court must have intended that it would always be unreasonable to discriminate against the plaintiff, if its appliance were otherwise safe. That is, an arbitrary denial of the seal of approval, without giving the plaintiff an opportunity to show either that its burner met the defendants' standards, or that those standards were unreasonable, would be unlawful per se.

Over the past dozen years, the Supreme Court, in a number of decisions, lias reaffirmed the principle that group boycotts are unreasonable per se. ${ }^{85}$ In its most recent decision involving group boycotts, St. Paul Fire

35. See, e.g., United States v. General Motors Corp., 384 U.S. 127 (1966). A "location clause" in the franchise agreement between General Motors and its dealers permitted GM to prevent the dealer from opening a showroom too close to another dealer. Chevrolet dealers in the Los Angeles area pressured GM to threaten to terminate the franchises of several dealers who were selling to discount houses, ostensibly because they violated the location clause. The Court found a conspiracy among the dealers, and between them and GM, to coerce competitors to conform or risk being driven out of business. The Court indicated that this conduct was unreasonable per se.

See also Silver v. New York Stock Exch., 373 U.S. 341 (1963); United States v. National Ass'n of Sec. Dealers, Inc., 422 U.S. 694, 729 (1975); Federal Maritime Comm'n v. Aktiebolaget Svenska Amerika Linien, 390 U.S. 238, 250 (1968); United States v. Sealy, Inc., 388 U.S. 350, 357 n.5 (1967); White Motor Co. v. United States, 372 U.S. 253, 259-60, 263 (1963); Continental Ore Co. v. Union Carbide \& Carbon Corp., 370 U.S. 690, 708 (1962). Similar statements also appeared in Ricci v. Chicago Mercantile Exch., 409 U.S. 289, 314 (1973) (Marshall, J., dissenting); Flood v. Kuhn, 407 U.S. 258, 287 \& n.2 (1972) (Douglas, J., dissenting); Haywood v. National Basketball Ass'n, 401 U.S. 1204, 1205 (1971) (Douglas, J.) (application for stay in chambers); and United States v. Container Corp. of America, 393 U.S. 333, 341 (1969) (Marshall, J., dissenting). 
$\&$ Marine Insurance Co. v. Barry, ${ }^{36}$ the Supreme Court hinted that it might be prepared to reexamine the scope of the per se rule. At issue in St. Paul was the extent of the exemption from the antitrust laws conferred on insurance companies by the McCarran-Ferguson Act. ${ }^{37}$ The Court was called upon to decide whether the term "boycott," as used in section 3(b) of the McCarran-Ferguson Act, had "its ordinary Sherman Act meaning as 'a concerted refusal to deal," 38 or was limited to boycotts by insurance companies of other companies or their agents. Although the Court opted for the former, broader definition, Justice Powell's opinion for the Court ${ }^{30}$ may prove significant for another reason-it may foreshadow a change in the strict per se approach to group boycotts. After first reviewing the legislative history of the McCarran-Ferguson Act, the opinion discussed some early group boycott cases and pointed out the different terminology which had been used to describe this particular conduct. It went on to note, in a passage that was clearly unnecessary for determination of the statutory construction issue, that there is some controversy as to what conduct comes within the per se rule.40 Then Justice Powell said: "But the issue before us is whether the conduct in question involves a boycott, not whether it is per se unreasonable." 41

Although it would be an exaggeration to assert that this is a clear indication that the Court is willing to reconsider the per se rule, the Sylvania case $^{42}$ suggests that such a change is not nearly as unlikely as it would have been even as recently as 1973 .

\section{B. Lower Court Reaction to the Supreme Court Rule}

The per se rule enunciated by the Supreme Court lias created a number of probleins in application for the lower courts. One problem has been defining what constitutes a group boycott. ${ }^{43}$ Although experience may allow

36. 438 U.S. 531 (1978).

37. 15 U.S.C. $\$ \S 1011-1015$ (1976).

38. 438 U.S. at 540. This definition of group boycott would have ineluded within tho unexempted conduct concerted refusals to deal with customers as well as with competitors of the insurance companies.

39. Justice Powell was joined by six other members of the Court. Justico Stewart wroto a dissenting opinion, in which Justice Rehnquist joined.

40. "Petitioners ... cite commentary that attempts to develop a test for distinguishing the types of restraints that warrant per se invalidation from other concerted refusals to deal that are not inherently destructive of competition." 438 U.S. at 542. After citing and summarizing a few of these approaches, the Court said: "We express no opinion, however, as to tho merit of any of these definitions." Id. n.14.

41. Id. The Court also quoted Professor Areeda for the proposition that " Boycotts aro not a umitary phenomenon." "Id. at 543 (quoting P. AREEDA, ANTITRUST ANALYSIS 381 (2d ed. 1974)).

42. Justice Powell was also the author of Continental T.V., Inc. v. GTE Sylvania Inc., 433 U.S. 36 (1977) - the first (and only) decision to overrule a per so rule.

43. See, e.g., International Rys. of Cent. America v. United Brands Co., 532 F.2d 231 (2d Cir.), cert. denied, 429 U.S. 835 (1976). The two defendants had been the principal customers of the plaintiff railroad. They made a joint decision, based on independent business considerations, to close down their Guatemalan banana plantations. This joint determination obviously meant that neither defendant would continue to do busmess with the plaintiff; 
us quickly to include certain conduct within this term, most situations are far more ambiguous. Therefore, in order to characterize the conduct - to decide whether it should be treated under a per se rule-lower courts have examined many of the same factors relevant under rule of reason analysis. ${ }^{44}$ For example, courts often consider the relationship between the agreeing parties. The per se rule apphies particularly, if not exclusively, to group boycotts where the parties to the agreement are competitors. ${ }^{45}$ Courts also consider the nature of the refusal; significantly different treatment has been given to boycotts im a commercial setting than to those which seek to achieve social or political goals, or those which are incident to a labor dispute. Even withim the commercial boycott setting, determination of whether to treat the conduct as within the per se rubric depends upon whether the intent of the parties is exclusionary-designed to injure or discipline the object of the boycott-or whether the conduct is designed to achieve other purposes which are neutral or even beneficial.

There have been scores of cases in the two decades since the Klor's decision which have reiterated that concerted refusals to deal are illegal per se. A smaller group of lower court decisions, however, while not disputimg the basic per se nature of the group boycott doctrine, have refused to apply the rule to the particular facts at bar. In other words, these courts have determined particular situations not to be group boycotts so that the Fashion Guild/Klor's line of cases can be distimguished. A number of rationales have been used to find that the challenged conduct did not fall within the per se rubric. Lower courts have looked to the defendant's lack

in response, the plaintiff argued that the defendants had engaged in a "concerted refusal to deal." The court, influenced by the fact that the defendants had decided to go out of business, held that the conduct should not be classified as a group boycott. The Court distinguished Fashion Guild and Klor's because they each involved "joint refusals to deal by viable business entities which deliberately and intentionally refused to deal with a trader although otherwise able." Id. at 241. See also Instant Delivery Corp. v. City Stores Co., 284 F. Supp. 941, 947 (E.D. Pa. 1968).

44. Under the rule of reason analysis, a court determines the reasonableness of any restraint, and hence the legality of the conduct, by considering:

the facts pecubiar to the business to which the restraint is applied; its condition before and after the restraint was imposed; the nature of the restraint and its effect, actual or probable[,] [t]he history of the restraint, the evil believed to exist, the reason for adopting the particular remedy, [and] the purpose or end sought to be attained ....

Chicago Bd. of Trade v. United States, 246 U.S. 231, 238 (1918) (Brandeis, J.).

The Supreme Court explained the per se approach's methodology recently in National Soc'y of Professional Eng'rs v. United States, 435 U.S. 679, 687-96 (1978). If the conduct falls within the rule of reason, a court will be allowed to weigh arguments about the competitive effects of the arrangement. On the other hand, once the conduct is brought within the per se rule, it is conclusively presumed that there will be a net adverse impact on competition. However, the per se rule does not foreclose inquiry as to the nature and effect of the restraint until the conduct has been characterized.

45. See notes 114-34 and accompanying text infra. A distinction can be drawn among (1) situations in which parties to the agreement are competitors, in which case the conduct is referred to as horizontal, (2) situations in which the parties are in an actual or potential buyer-seller relationship, in which case the conduct is referred to as vertical, and (3) situations where the parties have a different, more distant relationship. 
of exclusionary intent, ${ }^{46}$ to a reasonable economic need and justification for the conduct, ${ }^{47}$ or to a non-commercial setting for the restraint, ${ }^{48}$ to justify rule of reason analysis. In fact, several lower courts have held that the per se rule applies only to certain group boycotts, ${ }^{40}$ even though Supreme Court decisions do not contain any such limitations.

The next section of this Article will examime the policies underlying application of per se rules, and will conclude that, in view of the apparent confusion that the Klor's rule has engendered, such a broad per se rule should not apply to group boycotts. The final section will propose that certain group boycotts be treated under the rule of reason, and will suggest guidelines for determining when the per se rule should continue to apply.

\section{Per Se Rules: Limiting the Range of Flexibility}

\section{A. Per Se Approach or Rule of Reason: The Arguments}

Regardless of the specific conduct in question, numerous argunents support either a per se approach or a rule of reason approach to evaluation of the legality of a defendant's activities under section 1 of the Sherman Act. ${ }^{50}$ The courts have determined that certain classes of conduct are to be evaluated under a per se rule, and that others are subject to rule of reason analysis. ${ }^{51}$ This section of the Article will review those arguments briefly and then discuss their specific apphicability to concerted refusals to deal.

The most significant advantage of a per se approach is predictability. Once business executives know that the proposed activity falls within the rule, they-and lawyers counseling them-will not have to speculate on the evaluation that a future trier of fact will make of the nature and effect of

46. Oreck Corp. v. Whirlpool Corp., 579 F.2d 126, 132-33 (2d Cir.), cert. denied, 439 U.S. 946 (1978); Hatley v. American Quarter Horse Ass'n, 552 F.2d 646, 652-53 (5th Cir. 1977); E.A. McQuade Tours, Inc. v. Consolidated Air Tour Manual Comm., 467 F.2d 178, 187 (5th Cir. 1972), cert. denied, 409 U.S. 1109 (1973); Joseph E. Seagram \& Sons v. Hawaiian Oke \& Liquors, Ltd., 416 F.2d 71, 76-78 (9th Cir. 1969), cert. denled, 396 U.S. 1062 (1970).

47. Smith v. Pro Football, Inc., 593 F.2d 1173 (D.C. Cir. 1978); Ackerman-Chillingworth v. Pacific Elec. Contractors Ass'n, 579 F.2d 484, 490 n.7 (9th Cir. 1978), cert. denled, 99 S. Ct. 872 (1979); Mackey v. National Football League, 543 F.2d 606, 618-20 (8th Cir. 1976), cert. dismissed, 434 U.S. 801 (1977); Worthen Bank \& Trust Co. v. National BankAmericard Inc., 485 F.2d 119, 127 (8th Cir. 1973), cert. denied, 415 U.S. 918 (1974). See also Deesen v. Professional Golfers' Ass'n of America, 358 F.2d 165, 170 (9th Cir.), cert. denied, 385 U.S. 846 (1966).

48. Marjorie Webster Junior College, Inc. v. Middle States Ass'n of Colleges \& Secondary Schools, Inc., 432 F.2d 650, 654 (D.C. Cir.), cert. denied, 400 U.S. 965 (1970).

49. Neeld v. National Hockey League, 594 F.2d 1297, 1298-99 (9th Cir. 1979); Smith v. Pro Football, Inc., 593 F.2d 1173, 1179-80 (D.C. Cir. 1978); North Am. Soccer League v. National Football League, 465 F. Supp. 665, 672-74 (S.D.N.Y. 1979); Hunt v. Mobil Oil Corp., 465 F. Supp. 195, 214 (S.D.N.Y 1978). See note 73 infra.

50. See generally Bork, The Rule of Reason and the Per Se Concept: Price Fixing and Market Division (pts. 1-2), 74 YALE L.J. 775 (1965), 75 YALE L.J. 373 (1966); Elman, "Petrified Opinions" and Competitive Realities, 66 Colum. L. Rev. 625 (1966); Loevinger, The Rule of Reason in Antitrust Law, 50 VA L. Rev. 23 (1964); von Kalinowski, The Per Se Doctrine-An Emerging Philosophy of Antitrust Law, 11 U.C.L.A. L. REv. 569 (1964).

51. See notes $2-3$ and accompanying text supra. 
the conduct. Instead, there is the assurance of knowing that it is not worthwhile even attempting the conduct, in the hope of justifying it afterwards.

A per se approach also results in a higher level of deterrence by wideming the scope of the forbidden. Knowing that the conduct is always prohibited, the company will hesitate to engage even in conduct closely resembling it, since the penalties for erring are severe. Certain conduct which the law would like to deter, but which might go unchallenged or be enjomed only after several years, would simply not be undertaken.

The per se approach also has substantial administrative advantages. If the legality of particular conduct is subject to individual and varying appraisals of its history, purpose, nature, and effect, the trier of fact will have to permit introduction of, and analyze, a large volune of evidence. The plaintiff-either an enforcement agency or a person asserting a private cause of action-will have to go to great trouble and expense to amass that evidence. If, instead, the plaintiff's burden of proof is satisfied simply by showing that the proscribed conduct did occur, there will be substantial savings of time and money to the parties and the courts. ${ }^{52}$

Finally, allowing cases to go to the trier of fact may mean that occasional "wrong" decisions will occur. Use of a per se approach thus decreases the possibility that some judges or juries will approve of conduct which should have been condemned.

These advantages must be balanced against the serious costs which can result from overly broad per se rules. Although a per se rule might offer predictability, there is no advantage to society in proscribing business conduct which is harmless or even beneficial. The advantage of a flexible rule is that it will effectively proscribe only harmful conduct, leaving other conduct untouched. Therefore, a per se rule slould not foreclose any activity which carries a reasonable likelihood that it will have no adverse effect on competition.

Indeed, the statement of the justification for particular per se rules takes this approacli. They are said to be appropriate, and have been adopted, only in those situations where experience has shown that one so rarely expects any benefit to competition that it is not worth pursuing the inquiry to identify the few neutral or beneficial situations which might arise. ${ }^{53}$ The growtl1 in the number of categories of conduct falling within

52. As a variation to this rationale, courts have recognized that their ability to make the economic determinations involved in weighing the impact on competition of certain forms of conduct is limited. In the words of Justice Marshall, courts are reluctant to "ramble through the wilds of economic theory in order to maintain a flexible approach." United States v. Topco Assocs., 405 U.S. 596, 609-10 ח.10 (1972).

53. See, e.g., Northern Pac. Ry. v. United States, 356 U.S. 1, 5 (1958): "[T]here are certain agreements or practices which because of their pernicious effect on competition and lack of any redeeming virtue are conclusively presumed to be unreasonable and therefore illegal without elaborate inquiry as to the precise harm they have caused or the business excuse for their use." See also Continental T.V., Inc. v. GTE Sylvania Inc., 433 U.S. 36, 50 n.16 (1977); United States v. Container Corp. of America, 393 U.S. 333, 341 (1969) (Marshall, J., dissenting). 
the per se rules is said to be based on increased experience by the courts with that conduct. In the first few decades of antitrust enforcement, a rule of reason inquiry was undertaken. Only in light of several cases reaching a uniform conclusion was it deemed appropriate to foreclose this obviously futile inquiry in future similar situations.

In its statements that per se rules are justified after experience has shown the very small probability that the conduct will on balance be procompetitive, the Court could hardly inean that there has been empirical evidence to justify the ban. The Court can at best mean that the several cases where that conduct has been presented all resulted in a conclusion that the conduct was unreasonable; analysis and intuition suggest that no future conduct is likely to have sufficiently novel characteristics that the ultimate conclusion would differ. Since it is unlikely that such a per se rule would proscribe neutral or beneficial conduct, and in view of the substantial benefits described above of a per se approach, the foreshortening of the analysis is justified.

\section{B. Group Boycotts: The Evil Justifying Per Se Treatment}

For the past several decades, the Supreme Court has held that group boycotts, or concerted refusals to deal, are unlawful per se.54 It has held equally clearly that a unilateral refusal to deal is not proscribed by the Sherman Act. ${ }^{55}$ Unless it is attempting to create or mamtain a monopoly, ${ }^{50}$ a company, acting alone, can refuse to sell to anyone else. It does not matter that the company is trying to coerce its customers to adhere to a certain kind of conduct-for example, the maintenance by the customer of a suggested resale price - and is using the threat of refusal of future sales as the bargaining chip..$^{57}$ Similarly, a company may lawfully attempt to get its supplier to refuse to sell to the company's competitors, and use its buying power as the threat to accomplish this cutoff, although the result of the threat might be that the company's rivals will be driven out of business. ${ }^{58}$

One explanation for this rule is that simple unilateral threats do not fall within the statutory language of section 1 of the Sherman Act, which

54. See notes 12-33 and accompanying text supra.

55. See, e.g., Umited States v. Colgate \& Co., 250 U.S. 300, 307 (1919); Eastern States Retail Lumber Dealers' Ass'n v. United States, 234 U.S. 600, 612 (1914).

56. If the defendant's conduct is actuated by a specific intent to achieve a monopoly in a particular market, and there is a dangerous probability that the refusal to deal will allow it to obtain that monopoly, this unilateral conduct may be unlawful under $\$ 2$ of the Sherman Act. 15 U.S.C. $\$ 2$ (1976). See, e.g., Otter Tail Power Co. v. United States, 410 U.S. 366 (1973); Poller v. Colunibia Broadcasting Sys., 368 U.S. 464 (1962); Lorain Journal Co. v. United States, 342 U.S. 143 (1951).

57. United States v. Colgate \& Co., 250 U.S. 300 (1919). But see United States vo Parke, Davis \& Co., 362 U.S. 29 (1960). See generally Barber, Refusals to Deal Under the Federal Antitrust Laws, 103 U. PA. L. Rev. 847 (1955).

58. FTC v. Rayinond Bros.-Clark Co., 263 U.S. 565 (1924); Packard Motor Car Co. v. Webster Motor Car Co., 243 F.2d 418 (D.C. Cir. 1957). See also Oreck Corp. v. Whirlpool Corp., 579 F.2d 126 (2d Cir.) (en banc), cert. denied, 439 U.S. 946 (1978); text accompanying notes 129-33 infra. 
requires a "contract, combimation ... or conspiracy." 59 Another explanation is the somewhat hallowed notion that a company, acting unilaterally, has some "natural freedom" to choose whether it will sell to, or buy from, someone else. ${ }^{60}$ But these rationales, taken alone, hardly explain why the unilateral refusal to deal appears to be "per se lawful," while the concerted refusal to deal is, to the contrary, per se unlawful.

The Court inched towards an explanation of this different treatment in Paramount Famous Lasky Corp. v. United States ${ }^{61}$ when it pointed to the added coercive power that was obtained when a company, in a business dispute with its customers, enrolled the market power of its competitors so as to achieve a result which it might not be able to achieve were it actimg alone and thus relying only on its own market power. ${ }^{62}$ Somehow, the escalation of a bilateral dispute into the threat of an imdustry-wide boycott transformed the lawful into the condemned. ${ }^{63}$ Yet, the use of joint market power by two competitors, even if it has injurious effects on others, is not in itself unlawful. When two rivals merge to form a new, bigger company, they are entering into a "contract, combination . . . or conspiracy" which may adversely affect their competitors. Indeed, the merged company may be strong enough-because of its new inarket power-to force rivals to conform to a certain type of conduct or go out of business. Most horizontal mergers are nonetheless permitted, because they may result in efficiencies which yield lower prices, better and cheaper goods or services, and increased consumer utility. ${ }^{\text {of }}$ In order to justify the per se rule there must not only

59. Section 1 of the Sherman Act is implicated only when there is a plurality of actors. This jurisdictional requirement, which is reflected in the proscription of a "contract, combination, ... or conspiracy," is sometimes replaced by the near-synonym "agreement." The agreement may be implied as well as express, may be covert as well as overt, and may be inferred from circumstances or observed from explicit and clear evidence. See, e.g., United States v. General Motors Corp., 384 U.S. 127, 142-45 (1966); Interstate Circuit, Inc. v. United States, 306 U.S. 208, 221 (1939).

60. United States v. Colgate \& Co., 250 U.S. 300, 307 (1919). This explanation is supported by a provision in the Robinson-Patman Price Discrimination Act: "N]othing lierein contained shall prevent persons engaged in selling goods, wares, or merchandise in commerce from selectimg their own customers in bona fide transactions and not in restraint of trade." 15 U.S.C. $\$ 13$ (a) (1976).

61. 282 U.S. 30 (1930); see notes 19-21 and accompanying text supra.

62. The evil in Paramount may have been that the companies had agreed, in advance, to refuse to do business with exhibitors, thereby foreclosing an independent investigation by each competitor of the merits of the original underlying dispute. Each producer-distributor would be barred from doing business with the exhibitor, even if it thought that its competitor's demands were unjustified. Instcad, the joint refusal to license motion pictures liad the effect of making the exhibitor submit to the distributor's demand even when it felt that its position was correct. See also United States v. First Nat'l Pictures, Inc., 282 U.S. 44 (1930). See also St. Paul Fire \& Marine Ins. Co. v. Barry, 438 U.S. 531, 543-46 (1978).

63. One particularly troubling characteristic of some concerted conduct is that the refusal to deal may be the subject of extensive rules, making the defendants a "private government." Thus, in Fashion Originators' Guild of America, Inc. v. FTC, 312 U.S. 457, 462-63, 465 (1941), the defendants employed "[a]n elaborate system of trial and appellate tribunals .... for the determination of whether a given garment is in fact a copy of a Guild member's design." This was found to constitute "an extra-govcrnmental agency, which ... provides extra-judicial tribunals for determination and punishment of violations, and thus trenches upon the power of the national legislature . ..." See also Associated Press v. United States, 326 U.S. 1, 19 (1945).

64. See, e.g., Brown Shoe Co. v. United States, 370 U.S. 294 (1962) (interpreting § 7 of the Clayton Act, 15 U.S.C. $\$ 18$ (1976)). 
be an evil-for example, the use of joint market power-but also the absence of probable competitive benefit which would justify the conduct. One key aspect of the analysis, then, is whether concerted refusals to deal might be believed never to result in these kinds of benefits to competition.05 If so, the suspected injury would be less willingly tolerated.

The fact that concerted refusals to deal involve a combination of market power does not in itself indicate the effect-the exact mjury-caused by the practice. As noted, group boycotts result im the inability of some members of the commercial community to buy from, or sell to, others-either absolutely or only in conformity with certain conditions. Since the antitrust laws tolerate unilateral refusals to deal, however, the concerted effort must be condemned not only because we object to the use of cooperative market power, but also because the effect of the boycott is sufficiently objectionable.

Obviously, a group boycott can either drive competitors completely from the inarket or make it significantly more difficult for them to compete. It is a basic premise of antitrust jurisprudence that the vigor of competition is directly linked to the number of competitors. The antitrust laws ought at least view critically, even if they do not always condemn, activities which might tighten any existing oligopoly. The Supreme Court has stated its preference for an econoiny characterized by deconcentration-many companies, each with a snall share of the market-and freedom of entry and exit. Thus, even if the victim's market is rather deconcentrated, a course of conduct by some businesses which drives another from the market is undesirable. ${ }^{66}$ Under this view, the Sherman Act is designed to protect firms from those forms of "unfair practices" which will drive them from the market. ${ }^{67}$ The phrase "unfair" covers a world of sins, and depends heavily on the antitrust philosophy of the definer; nonetheless, it is reasonable to condemn exclusionary practices unless there is another value furthered by allowing them to continue ${ }^{68}$ or unless they yield other competitive benefits.

Even if the boycotted party is not eliminated or diminished as a nuarket force, the concerted refusal to deal may deprive the firm of entrepreneurial freedom and force it to conform to conduct-such as pricing, selection of goods sold, choice of suppliers or customers-which is arbitrarily determined by another. Absent the boycott, a company might bring new products on the market, sell through new distributive channels or to different customers, offer new services to consumers, or package the product differently. The concerted refusal to deal deprives the businessman of this flexibility, and

65. There are, however, certainly situations presenting such efficiencies. For example, in Associated Press $v$. United States, the parties to a joint venture refused to sell news to nonmembers. It might be argued that this restriction was initially required to induce the investnient of venture capital, and continued to be required to promote the efficient distribution of the product among the joint venturers. The per se rule apparently would foreclose all assertions of even these limited efficiencies as a defense to a concerted refusal to deal.

66. Klor's, Inc. v. Broadway-Hale Stores, Inc., 359 U.S. 207 (1959).

67. See Northern Pac. Ry. v. United States, 356 U.S. 1, 4 (1958). See also United States v. Topco Assocs., 405 U.S. 596, 610 (1972).

68. See, e.g., text accompanying note 60 supra. 
may therefore rob society of lower prices, better quality products and services, and ultimately of goods themselves. In view of these potential exclusionary effects, and bearing in mind the general advantages of the per se approach described above, the courts may reasonably require some competitive benefits from group boycotts before permitting this conduct.

Three different potential justifications for permitting group boycotts can be identified. (1) There is a compelling need in the industry for this conduct; elimination of some competition is required in order for the industry to operate efficiently. (2) Although there are admittedly no benefits to competition from the group boycott, there are other societal benefits froin the restraint and only minimal competitive injuries. (3) The particular restraint, while admittedly not yielding any competitive benefits, also does not injure competition; it is "neutral" conduct about which the antitrust laws should be unconcerned.

The first possible justification-the compelling need argument-has had a mixed reception in the courts. With regard to price-fixing, the assertion that there is too much competition in an industry, and that therefore pricefixing is needed by the industry members to protect themselves and ultimately the public, has been flatly rejected.69 That the result should be the same with concerted refusals to deal is not clear.

In Fashion Originators' Guild of America, Inc. v. FTC, ${ }^{70}$ the defendants argued that they were forced to resort to concerted refusals to deal in order to eliminate a form of unfair competition; they asserted that they were being victimized by persons copying their designs, for wlich there was imadequate relief under state tort law. The Court rejected their argument, simply asserting that the antitrust laws do not permit the elimination of competition in order to destroy other competitors. In at least certain areas, however, conduct which diminishes competition may be permitted if the courts are sympathetic to the industry needs. The clearest examples arise in professional sports cases. For example, although football teams compete in certain respects-both on and off the field-they may be permitted to impose upon each other restraints on the right to bid competitively for the services of graduating college players, ${ }^{71}$ or to negotiate with the players of the other teams. ${ }^{72}$ Thus, the National Football League (NFL) uses a "draft system," assigning the rights to negotiate with graduating collegiate stars to individual teams. The other League members have agreed in advance that they will not compete for that player's services (they concertedly refuse to

69. United States v. Socony-Vacuum Oil Co., 310 U.S. 150, 220-22 (1940); United States v. Addyston Pipe \& Steel Co., 85 F. 271 (6th Cir. 1898), aff'd, 175 U.S. 211 (1899). But see Appalachian Coals, Inc. v. United States, 288 U.S. 344 (1933).

70. 312 U.S. 457 (1941). See notes $22-23$ and accompanying text supra.

71. Smith v. Pro Football, Inc., 593 F.2d 1173 (D.C. Cir. 1978) (draft of collegiate players is not a concerted refusal to deal subject to the Klor's per se rule; however, the draft is an unreasonable restraint of trade).

72. Mackey v. National Football League, 543 F.2d 606, 618-22 (8th Cir. 1976), cert. dismissed, 434 U.S. 801 (1977) ("Rozelle rule" not unlawful per se, but unlawful under rule of reason). 
deal with him), forcing the player to negotiate with one team or forego playing in the League altogether. ${ }^{73}$ Similarly, the NFL has adopted the so-called "Rozelle rule," which allows the NFL Commissioner to require a team acquiring a free agent from another team to compensate that player's former team. The result of this rule is to eliminate the interest of some teams in the services of some players; indeed, sometimes the effect will be that all teams jointly refuse to deal with the free agent. Nonetheless, it need not follow that the draft system or the Rozelle rule inust be labeled per se unlawful. The courts may recognize that unbridled competition in that industry would be destructive, and that certain agreements by competitors not to do busmess with third parties may occasionally be necessary. ${ }^{74}$

73. The court in Smith v. Pro Football, Inc., 593 F.2d 1173 (D.C. Cir. 1978), sought to avoid the Klor's rule by stating that it only applied to "a concerted attempt by a group of competitors at one level to protect themselves from competition from nongroup members who seek to compete at that level." Id. at 1178. Support for this appronch was found in Professor Sullivan's treatise. He argued that "the per se rule applies only to classic boycotts," which he then defined as "an effort by a group of traders to exclude or inhibit a competitor trying to enter or compete in their market either by themselves not denling with the competitor or by coercing or inducing one or more suppliers or customers not to deal with him." L. Sullivan, supra note 5 , at 255 n.5. See also id. at 259 . The court in Smith then observed that "the NFL clubs . . . are not competitors in any economic sense." 593 F.2d at 1178-79 (emphasis in original).

This analysis is flawed on two counts. First, although the court observed that, unlike the normal business situation, no football team vauts to drive another team out of business, the clubs nonetheless engage in very vigorous competition in scouting out the best players and bidding for their services. Absent the draft rule, the teams would bid up the prices for player services-the very essence of competition; the draft rule eliminates that price competition by denying potential alternate employers to the drafted player. Indeed, in the section of the opinion evaluating the draft under the rule of reason, the court focused on this anticonpetitive effect as the basis for finding it unlawful. Id. at 1183-89. Second, Klor's itself does not fit within the facts of the court's reformulation of an illegal concerted refusal to deal. There, the manufacturer-conspirators were not seeking to "protect themselves from competition from non-group members"; the object of the boycott was a buyer from those defendants, who apparently was being disciplined for engaging in price cutting. See note 118 and accompanying text infra. Therefore, Professor Sullivan's proposed limitation on Klor's may not accurately reflect the present law.

The Smith decision points out the difficulties courts experience with the present per se rule. In addition to resorting to characterization-saying that this conduct was not a group boycott within the neaning of Klor's-the court also noted that there is authority for recognizing "two types of group boycotts-'per se boycotts' and 'rule of reason boycotts." "593 F.2d at 1179 n.22. Until Klor's is nodified by the Supreme Court, it is inappropriate for lower courts to disregard its rather clear statement of the per se rule. Rather, the courts wiil have to continue to struggle with the characterization approach. This nonetheless indicates the need for Supreme Court clarification of the scope of the rule.

74. An interesting exanple of the recognition by a court of the occasional need of industry menubers to resort to a group boycott for self-protection is Florists' Nationwide 'Tel. Delivery Network v. Florists Tel. Delivery Ass'n, 371 F.2d 263 (7th Cir.), cert. denied, 387 U.S. 909 (1967). The defendant association (FTD) consisted of a nationwide network of florists, the objective of which was to allow a retail customer to place an order for flowers in one city, for delivery by an association member florist in another city. The plaintiff organized a sub-group of that association, made up of a maximum of one florist in each city who was designated as a "selected" member of FTD. The menbers of this sub-association then hoped that each would channel its order in another city to another member, rather than having the remote florist chosen at random. Nonmembers of the plaimtiff's association com. plained that they were losing business. In response to these complaints, the defendant adopted new rules which prohibited its nuembers from joining organizations like the plaintiff's; membership in the plaintiff's organization fell off drastically. The plaintiff charged that the new by-laws resulted in a group boycott of his service and of the members of the association.

The jury returned a verdict for the plaintiff, despite the trial court's instructions that 
Rather than resort to the per se approach, the courts have used the rule of reason to determine if there is a less restrictive alternative that can achieve that goal. ${ }^{75}$

Examples of the second possible justification for group boycotts-other societal benefits-are frequently, though not always, found in situations where the alleged refusal to deal, although in a commercial setting, is designed to achieve non-commercial (or non-economic) goals. Thus, in Radiant Burners, ${ }^{76}$ the defendants were accused of acting in concert to prevent the sale and use of the plaintiff's gas burner. Although it is true that absent the defendants' conduct there would have been an additional product on the market, resulting in increased competition for sales in that industry, there would have been great societal injury if the burner had been unsafe. The remand of the case for trial, rather than directing entry of judgment for plaintiff because of defendants' admitted refusal to certify the plaintiff's product, indicates the Court's belief that the loss of competition might be more than offset by the protection of the public.

This kind of analysis is admittedly inconsistent with the per se approach, at least as regards price-fixing. In National Society of Professional Engineers v. United States, ${ }^{77}$ the Court rejected out of hand the same

there must be a finding that the by-laws "were adopted and published with specific intent to destroy plaintiff's business." Id. at 269. On appeal, the Court of Appeals for the Seventh Circuit, distinguishing Supreme Court cases supporting a per se rule on their facts, lield that the defendant's conduct was lawful. The court found that the defendant had merely been reacting to what it characterized as the plaintiff's "deceptive activities." Id. at 270.

This lolding seems inconsistent with Fashion Guild. There, the Supreme Court had assumed that the conduct of the "style pirates" not only was unfair, but perhaps even tortious. The Court nonetheless held that concerted refusals to deal with others, with the knowledge and intent that they miglit be driven out of business as a result, were unreasonable witlout more: "[E]ven if copying were an acknowledged tort under the law of every state, that situation would not justify petitioners in combining together to regulate and restrain interstate commerce in violation of federal law." 312 U.S. at 468 . If the per se rule were applied, the alleged justification of defendant FTD-"that the FTD rules complained of are but reasonable methods of self-protection against such boycott and unfair and deceptive advertising practices on the part of [defendant]," 371 F.2d at 267-should be equally irrelevant and unavailing.

75. Restrictive agreements involving professional sports groups have been the subject of several cliallenges under the concerted refusal to deal theory. In addition to the Smith and Mackey decisions discussed in notes 71-73 and accompanying text supra, see, e.g., Neeld v. National Hockey League, 594 F.2d 1297 (9th Cir. 1979); Deesen v. Professional Golfers' Ass'n of America, 358 F.2d 165 (9th Cir.), cert. denied, 385 U.S. 846 (1966); North Am. Soecer League v. National Football League, 465 F. Supp. 665, 672-77 (S.D.N.Y. 1979); Robertson v. National Basketball Ass'n, 389 F. Supp. 867 (S.D.N.Y. 1975); Kapp v. National Football League, 390 F. Supp. 73, 80-81, 88-89 (N.D. Cal. 1974); Philadelphia World Hockey Club, Inc. v. Philadelphia Hockey Club, Inc., 351 F. Supp. 462, 504, 518 (E.D. Pa. 1972); Molinas v. National Basketball Ass'n, 190 F. Supp. 241 (S.D.N.Y. 1961).

The antitrust problems of professional and collegiate athletes-with frequent emphasis on concerted refusals to deal-liave been the subject of some concern by student law review authors. See, e.g., Comment, National Football League Restrictions on Competitive Bidding for Players' Services, 24 Bufralo I. Rev. 613 (1975); Note, The Super Bowl and the Sherman Act: Professional Team Sports and the Antitrust Laws, 81 HARv. L. Rev. 418 (1967); Comment, Player Control Mechanisms in Professional Team Sports, 34 U. Prr. I. REV. 645 (1973); Note, Tackling Intercollegiate Athletics: An Antitrust Analysis, 87 YaLE L.J. 655 (1978); 9 CONN. L. Rev. 336 (1977); 7 CuM. L. Rev. 505 (1977); 15 DuQ. L. Rev. 747 (1977); 59 MarQ. L. Rev. 632 (1976); 55 Neb. L. ReV. 335 (1976).

76. Radiant Burners, Inc. v. Peoples Gas Light \& Coke Co., 364 U.S. 656 (1961).

77. 435 U.S. 679 (1978). 
sort of argument-that price-fixing which might result in higher fees for engineers was justified by concerns for public safety, in that cost-cutting engineers might design unsafe buildings or bridges. The Court held that the Sherman Act had already made the judgment that competition was the predominant value; the only proper inquiry would be whether the imjury to competition from the restraint was offset by some benefit to competition in another form. Unlike the price-fixing situation, however, the justification of societal benefit appears not completely foreclosed when the conduct in question is a group boycott.

The third potential exception from the per se rule governing concerted refusals to deal concerns those forms of conduct which are neutral, in that they lave no significant effect either way on competition. The very existence of this category seems to be inconsistent with the basic philosophy of the per se approach, which posits that all group boycotts injure competition. Yet the lower courts have recognized some group boycotts about which the antitrust laws can be unconcerned.

The most cominon situations falling in this third category are boycotts in a non-commercial setting, that is, either where the defendants are not businessmen or where their objective in implementing the challenged activity is not to make a profit. ${ }^{78}$ It is true that even a "non-commercial" boycott - a refusal to buy from or sell to another-will have some effect on competition, at least in the microeconomic sense. Assume that a political organization, im an effort to achieve some goal, urges its members not to patronize stores until the store owners comply with the group's demands. There will indeed be some impact on competition-the boycotted stores will sell less, while the non-boycotted stores will have less competition and will sell more goods or will raise prices and profit levels. Nonetheless, most courts have looked at the intent, or purpose, of the boycotting parties and, if a non-commercial motive has been discerned, have found the conduct lawful under the Sherman Act. ${ }^{78}$ The rationale is as follows: an effect on competition will result from any decision respecting what and from whom one will buy or sell; where the effect, however, is incidental or ancillary to the non-commercial conduct, it may be characterized as not "affecting" competition within the meaning of the antitrust laws.

Although there is authority for distinguishing commercial and noncommercial restraints, this analysis is too simphistic. ${ }^{80}$ It does not make the critical distinction between conduct which is designed to have, and will probably have, the condemned evil effect on competition and conduct not motivated by the requisite intent or having such an effect.

78. See Bird, Sherman Act Limitations on Noncommercial Concerted Refusals to Deal, 1970 DURe L. J. $247,249$.

79. See note 102 infra.

80. See text accoinpanying note 102 infra. 


\section{Proposed Reformulation of the RUle}

\section{A. Introduction-The Need for a New Synthesis of the Rule}

In general, courts have sanctioned per se rules when experience has shown that the conduct is so likely to have net anticompetitive effects that it is not worth expending judicial and law-enforcement resources to identify the occasional procompetitive instances of the conduct. The Supreme Court's experience with group boycotts, however, has not been sufficient to justify institution of a per se rule. The present breadth of the per se rule can be explained in part by the concerted refusals to deal actually encountered in the Supreme Court decisions. In all of those cases, the allegations or evidence was that the conduct was designed for purely economic reasons-to coerce the object of the boycott to conform to a certain type of conduct, and perhaps even to drive it out of business. Furthermore, the only probable effect was the elimination of a form of competition. ${ }^{81}$

The labeling of concerted refusals to deal as per se unlawful creates a number of probleins. First, because the Supreme Court has never defined with care the conduct to be covered, the rule is naturally subject to varying interpretations by lower courts. Second, even if the conduct covered by the rule were defined more precisely, parties and the courts would disagree about the exact nature and effect of the conduct in question. ${ }^{82}$ Examinations of

81. In Fashion Guild, the defendants frankly admitted that they sought to drive the "style pirates" out of business. 312 U.S. at 461 . In Klor's, the defendants admitted that the result of their conduct might be to drive the plaintiff out of business; they defended in part on the ground that there were hundreds of similar merchants in town, and competition would not be injured even if the plaintiff were forced froin the scene. 359 U.S. at 209-10. The effect of defendants' conduct might have been minimal, but it was clearly anticompetitive, and if freely repeated would have had a serious impact in the long run. In General Motors, the auto dealers were upset that some of their competitors were selling to discount houses; they urged their supplier to use the threat of a refusal to deal to coerce those competitors into refraining from that business practice. 384 U.S. at 127 . The effect was to deny to consumers an alternative source of the product and to enhance its price.

82. Professor Sullivan resorts to a variation of the characterization approach to solve the problem of an overinclusive rule by creating two forms of boycotts. The first, the "explicit boycott", is "one in which the perpetrators agree not to deal with the victims or request (or demand that) others not deal with the victims." I. SullivaN, supra note 5, at 241 n.1. In contrast "are situations where firms at one level take joint action ... which may have the foreseeable but indirect effect of inducing others not to deal with one or more of the competitors of the firms which took the joint action." Id. Sullivan apparently would treat explicit boycotts as uulawful per se, while the second (unnamed) category would receive rule of reason treatment. Id. at $244 \&$ n.9, 252.

There are two important problems with this approach. First, making application of the per se rule turn on whether an effect is direct or indirect provides no firm guidance to the lower courts, which will then be submerged in such needless preliminary determinations as foreseeability and proximate cause. Second, the direct-indirect distinction gives insufficient emphasis to the defendants' purposes in engaging in the arrangement or the extent of the adverse effect of the restraint on competition. As indicated below, see notes 89-110 and accompanying text infra, these should be the principal focuses of any analysis of concerted refusals to deal.

Professor Bork takes a somewhat different approach. "[A]nalysis indicates that per se illegality should be reserved for naked boycotts, those not accompanying a lawful joint economic endeavor. When a boycott is found in the context of lawful joint economic behavior, it is not automatically lawful, for the law must still be satisfied that the restraint is aimed at creating efficiency rather than destroying or coercing rivals by means that do not benefit consumers. Boycotts that enhance efficiency may be called ancillary, while those that 
justifications for the conduct are therefore permitted at the back door just when the front door seems to have been barred.

Finally, in recent years the Court has created two different categories of per se rules. One-the "pure" rule-provides that the conduct (once identified) is always forbidden, regardless of any other factors. Price-fixing is the clearest example of this approach. On the other hand, the "modified" per se rule applies only after certam preconditions are met. Thus, tying arrangements are not always unlawful; they become unlawful per se only when the defendant has "sufficient economic power with respect to the tying product to appreciably restrain free competition in the market for the tied product and a 'not insubstantial' amount of interstate commerce is affected." 83 Similarly, there has been some suggestion that the exchange of price information among competitors should be deemed price-fixing, and hence per se illegal, only if the defendants have a substantial share of the market. ${ }^{84}$ Although the Supreme Court has never suggested that group boycotts should be handled under a modified per se rule, some lower court decisions suggest that such a rule does in fact exist. ${ }^{85}$

It seems clear that a serious reexamination of the nature and scope of the rule regarding group boycotts is appropriate. The first step in this reevaluation must be an explicit statement from the Supreme Court of why (or whether) group boycotts are deserving of per se treatment. Although the Court in Fashion Guild facilely compared the effect of group boycotts to that of price-fixing, ${ }^{86}$ there has simply never been an analysis of the universal evils of group boycotts. Once the Court has explaimed why at least certain types of group boycotts always have this anticompetitive effect, it must define-carefully and specifically-the conduct which is within the forbidden category. All other conduct should be evaluated under the rule of reason. The preceding discussion contains some explanation of why at least some concerted refusals to deal may be sufficiently universally anticompetitive as to be deserving of per se treatment, ${ }^{87}$ and also of why a

accompany a joint endeavor but are actually predatory may be called disguised naked boycotts." R. BORK, THE ANTITRUST PARADOX 334 (1978). This approach is characteristic of Professor Bork, who would measure all conduct in terms of advancement of allocative efficiency or consumer weifare. See, e.g., id. at 7-9, 50-56. But this single-minded approach fails to recognize that efficiency and injury to competitors are not polar positions.

Professor Bork criticizes the Court in Fashion Guild for its failure to consider the possibility that the defendants "were seeking to obtain the advertising and promotional advantages that exclusive dealing confers, and such an object ought not to be illegal." $I d$. at 339. It is also clear, however, that those defendants were attempting to achieve these efficiencies by a system intended to drive competitors from the market. Thus, Professor Bork's test either is of dubious guidance for future decisions, or worse, would permit some obviously coercive and anticompetitive kinds of conduct.

83. Northern Pac. Ry. v. Umited States, 356 U.S. 1, 6 (1958).

84. M. Handler, H. Blake, R. Prtofsky \& H. Goldschmid, Cases and Materials on Trade Regulation 333 (1975).

85. See, e.g., Oreck Corp. v. Whirlpool Corp., 579 F.2d 126, 131 (2d Cir.), cert. denled, 439 U.S. 946 (1978); Smith v. Pro Football, Inc., 593 F.2d 1173, 1180 nn.24 \& 25 (D.C. Cir. 1978); North Am. Soccer League v. National Football League, 465 F. Supp. 665, 673-74 (S.D.N.Y. 1979).

86. See 312 U.S. at 468.

87. See notes $62-68$ and accompanying text supra. 
sweeping per se rule covers too much. ${ }^{88}$ This section of the Article will therefore suggest a formulation of the definition the Court should use to differentiate between the two categories.

\section{B. Guidelines for a New Rule}

Courts should apply a per se rule to group boycotts only when two conditions are met: first, the conduct must be intended to coerce or exclude other entrepreneurs; second, the conduct must be likely to have anticompetitive effects. A third factor-the defendant's market power-nay bear on the purpose of a concerted refusal to deal and its likely effect; courts should be less disposed to apply the per se rule where the defendant's share of the market is small.

Unless both of these conditions are met, the court should apply the rule of reason. Situations in which concerted refusals to deal are not likely to meet these conditions can be divided into four broad categories: those in which the conduct is intended to protect the public from injurious activities; those that are intended to further political, social, or moral goals; those that are essential to efficient operation of the industry; and those in which economic benefits are realized. If conduct falls within one of these categories, it should be evaluated under the rule of reason. If not, the per se rule should continue to apply.

The factors that may determine whether a rule of reason should applythe significance of the defendants' intent, the effect of the restraint, and the defendants' market power-will be considered in turn. In addition, it will be necessary to examine another factor to which the courts have given much attention-the relationship between the parties. An analysis of several cases will indicate that undue reliance on this factor can lead to unjust results.

88. See notes $69-80$ and accompanying text supra.

An excellent example of an overly broad definition of a concerted refusal to deal is Premier Elec. Constr. Co. v. Miller-Davis Co., 422 F.2d 1132 (7th Cir.), cert. denied, 400 U.S. $828(1970)$. The defendant, a general contractor, had been invited to bid on a large construction project. The plaintiff, an electrical subcontractor, submitted to defendant a quotation for a portion of the project. The defendant told the plaintiff that its quotation was the lowest it received, and gave assurances that if it received the main bid, it would give the electrical job to the plamtiff; im return, the plaintiff agreed to submit padded high bids to the other general contractors. Although the defendant did receive the general contract, it then awarded the electrical subcontract to one of the plaintiff's competitors. The court held that "[o]n the basis of these pleadings the agreement between [defendant] and [plaintiff] constitutes a per se violation of the Sherman Act. By preventing [plaintiff] from submitting bids to other general contractors at the same prices made available to [defendant], the agreement constitutes a concerted refusal to deal." Id. at 1137.

This approach elevates an action for breach of contract, or for slick business dealings, into a per se violation of the antitrust laws. The plaintiff was not the object or victim of the boycott, but rather a party thereto. Furthermore, this purely vertical agreement would have had the effect of coercing or excluding other general contractors only if one assumes that there were no other electrical contractors who would be able to quote equally low prices; that is, if the plaintiff had substantial market power. Finally, the agreement could have been viewed simply as a restraint ancillary to an otherwise proper agreement to choose a supplier of subcontracting services. See Mitchel v. Reynolds, 1 P. Wms. 181, 24 Eng. Rep. 347 (K.B. 1711). The agreement not to supply competitive bids to the defendant's competitors should at best have been viewed as nothing more than partial consideration for the contract, and at worst, as an unreasonable restraint of trade. 
Finally, this section will discuss other factors which merit consideration once a court has determined that the rule of reason applies.

1. Defendants' Intent. The beneficent motives proffered by most companies regarding conduct which might injure competition are always suspect; we simply do not expect businesses to "be run as charitable institutions. Businesses are centers for the making of profits, and conduct is not anticipated which would run counter to this goal. It is obvious, lowever, that the fact that a company engages in conduct because of economic motivations does not mandate the proscription of those activities. The antitrust laws outlaw only conduct which is unfair or anticompetitive; section 1 of the Sherman Act proscribes only concerted action which results in an unreasonable restraint of trade. The courts must operate in the context of "objective intent," i.e., what a reasonable observer would infer as the purpose of the conduct in question, even though it may not be the justification offered by the defendants. For example, companies engaging in a price-fixing scheme may argue that their plan is designed to inake competition fairer or more open, or to protect competitors from the predatory practices of others. Courts have never felt bound to accept these rationales. ${ }^{80}$ The defendants will be said to have intended the reasonably probable effects of their conduct, even if they did not actually expect those results. ${ }^{90}$

There are, of course, countless exainples of business activity, actuated by a profit-making motive, which are not remotely within the interest of the antitrust laws. ${ }^{01}$ The rule of reason or the balancing of competitive effects required by sections 3 and 7 of the Clayton Act ${ }^{22}$ are a recoguition that those forms of conduct which yield efficiencies in production or distribution of goods or services are often lawful even if competitors may be injured in the process. Similarly, in evaluating a concertcd refusal to deal, courts shonld determine whether the defendants are seeking legitimate efficiencies or other societal benefits or are merely seeking to coerce or exclude competitors without any countervailing economic benefit. Finally, the doctrine should recognize conduct motivated principally by non-economic interests. Although we do not expect companies to be altruistic or public spirited for those reasons alone, there should be no objection to conduct, even in the form of a concerted refusal to deal, which is intended to promote the safety or welfare of the public, does not unnecessarily harm competitors, and may also have incidental benefits to the parties involved. ${ }^{93}$ The rule of reason

89. See, e.g., United States v. Socony-Vacuum Oil Co., 310 U.S. 150 (1940); United States v. Trenton Potteries Co., 273 U.S. 392 (1927); United States v. Addyston Pipe \& Steel Co., 85 F. 271 (6th Cir. 1898), aff'd, 175 U.S. 211 (1899).

90. United States v. United States Gypsum Co., 438 U.S. 422, $434-46$ (1978).

91. Almost every contract that a corporation enters into is motivated by the hope that the corporation will make money from the activity, either in the short or the long run. The result of a contract to sell a product to a customer may be to preclude the seller's competitors from making a similar contract, and will thereby "restrain competition" in the broadest sense of that phrase. But it is clear that to read the antitrust laws to reach such activity would make the laws not only unenforceable but meaningless.

92. 15 U.S.C. $\S \S 14,18$ (1976).

93. See Rahl, supra note 33, at 1172. 
should apply whenever concerted refusals to deal are motivated by a concern for the public health or safety. ${ }^{94}$

For example, the restraint might protect the public from injurious activities. This was the defendants' argument in Radiant Burners. ${ }^{95}$ The plaintiff alleged that the defendants had conspired, with anticompetitive motives, to deprive it of the seal of approval which was necessary for successful marketing of its product. The Court lield that the plaintiff should be entitled to slow that its product was as safe as those manufactured by the defendants and that the defendants conspired arbitrarily to deprive it of certification. The unstated corollary to the Court's conclusion must be that the defendants' joint refusal to certify the plaintiff's product, or to sell gas to others for use in that appliance, would not be unlawful under the Sherman Act if the burners were unsafe.

Similarly, the rule of reason rather than the per-se rule should apply to the enforcement by professional groups of legitimate ethical standards by means of sanctions which might include expulsion from the society and loss of the professional license. If a bar association, after finding that an attorney liad embezzled money from a client, were to expel that member, thereby preventing him from continuing to act as an attorney, the effect is a "group boycott" of that person and his elimimation as a competitor for offering professional services. This conduct is not motivated by an exclusionary intent, but ratlier by the desire to protect the public. Furthermore, its effect on competition will be minimal. ${ }^{96}$ The mere desire to act in the public interest would not necessarily immunize the defendants' conduct. However, these activities should be subject to a rule of reason inquiry, rather than being treated as if they were simply another variety of the conduct condemned in Fashion Guild and Klor's.

A second category of potentially permissible group boycotts consists of those designed to achieve non-commercial goals. ${ }^{97}$ Non-commercial boycotts are defined as refusals to deal by organizations not characterized principally by a profit-1naking motive, for example, by labor unions, educational institutions, or social or pohtical organizations. When the NAACP urged

94. Cf. Union Circulation Co. v. FTC, 241 F.2d 652, 656-57 (2d Cir. 1957) (agreement among employers not to hire competitors' former employees for one-year period, so as to prevent employees' fraudulent practices, not illegal per se, but unlawful under rule of reason); Structural Laminates, Inc. v. Douglas Fir Plywood Ass'n, 261 F. Supp. 154, 159 (D. Or. 1966), aff'd per curiam, 399 F.2d 155 (9th Cir. 1968), cert. denied, 393 U.S., 1024 (1969) (product standardization to promote quality control, which prevented plaintiff from making sales, not illegal group boycott).

95. Radiant Burners, Inc. v. Peoples Gas Light \& Coke Co., 364 U.S. 656 (1961). See notes $34 \& 76$ and accompanying text supra.

96. See National Soc'y of Professional Eng'rs v. Umited States, 435 U.S. 679, 686-96 (1978); Bates v. State Bar, 433 U.S. 350, 359-63 (1977); Goldfarb v. Virginia State Bar, 421 U.S. 773, 780-93 (1975); Bauer, Professional Activities and the Antitrust Laws, 50 Notre DaMe LAw., 570 (1975). Accord, Feminist Women's Health Center, Inc. v. Mohammad, 586 F.2d 530, 546-47 (5th Cir. 1978), petition for cert. filed sub nom. Palmer v. Feminist Women's Health Center, 47 U.S.L.W. 3761 (May 8, 1979) (No. 78-1689).

97. Compare Konecky v. Jewish Press, 288 F. 179 (8th Cir. 1923), with Council of Defense v. International Magazine Co., 267 F. 390 (8th Cir. 1920). See also Coons, NonCommercial Purpose as a Sherman Act Defense, 56 Nw. U.L. Rev. 705 (1962). 
that its supporters cease buying froin certain merchants, or cease patronizing the local bus system until seating was integrated, ${ }^{98}$ there was admittedly a joint refusal to do business with other parties which had adverse economic effects on those parties. ${ }^{99}$ Although the boycotters intended to force coinpliance with certain practices, and the effect of the boycotts may have been to drive certain firms out of business, the boycotters were seeking to achieve political or social, rather than cconomic, ends. ${ }^{100}$ Whether or not one agrees with the particular goal or tactic of the boycott, notions of political and economic freedom require that this activity be allowed. ${ }^{101}$ This does not mean, as a few cases and commentators liave suggested, that a narrow exception to the per se rule sliould be developed to exclude non-commercial boycotts. $^{102}$ Such an exception is too timid. It seems far more desirable

98. The NAACP's boycott activities have resulted in at least one litigated case asserting that the activities violated the antitrust laws, albeit those of the state of Mississippi rather than the Sherman Act. Claiborne Hardware Co. v. NAACP, No. 78,353 (Miss. Ch. Aug. 9, 1976), appeal docketed, No. 51,488 (Miss. Mar. 22, 1979). See Henry v. Nat'l Bank, 444 F.2d 1300 (5th Cir. 1971), cert. denied, 405 U.S. 1019 (1972). Cf. Watch Tower Bible \& Tract Soc'y v. Dougherty, 337 Pa. 286, 11 A.2d 147 (1940) (threats by clergy and parishioners to withdraw patronage from radio station and store controlling it unless station discharged broadcasters allegedly making bigoted remarks failed to state claim for interference with contractual rights); Kuryer Publishing Co. v. Messmer, 162 Wis. 565, 156 N.W. 948 (1916) (newspaper has no cause of action against clergy issuing pastoral letter prohibiting all parishioners from subscribing to, reading, or writing for plaintiff), discussed in Coons, supra note 97 , at $716-19$.

99. In 1963 the Birmingham, Alabama, retailers estimated that they were losing about $\$ 750,000$ per week because of the boy'cott of black customers and the added loss of business of whites who were afraid to come downtown. The blacks of Macon, Georgia, discontinued riding buses in 1962 to protest segregated seating. The bus company, suffering a 50 percent fare loss, gave in to the demands. The Evening Bulletin, a Philadelphia newspaper, estimated that it lost 25,000 to 50,000 subscriptions between April 15 and June 10, 1962, due to a boycott protesting certain policies regarding news about the black community.

Comment, The Consumer Boycott, 42 Miss. L.J. 226 (1971). See also Madison, Mississippi's Secondary Boycott Statutes: Unconstitutional Deprivations of the Right to Engage in Peaceful Picketing and Boycotting, 18 How. L. J. 583 (1975); Note, Political Boycott Activity and the First Amendment, 91 HaRV. L. REv. 659 (1978).

100. The National Organization for Women has promoted a boycott of states that have not yet ratified the Equal Rights Amendment (ERA). A primcipal objective is to persuade associations not to hold meetings and conventions in nonratifying states; the hope is that the loss of millions of dollars in revenue by business will influence legislators to vote for ERA. In Missouri v. National Organization for Women, Inc., 467 F. Supp. 289, 301-05 (W.D. Mo. 1979), the court refused to enjoin this boycott as unlawful under $\S 1$ of the Sherman Act. Although the court agreed that there was a combination or conspiracy, it held it outside the scope of the Sherman Act because of its "non-commercial" and "non-economic" nature. See also Nevada v. National Organization for Women, Inc., CIV-IV (D. Nev., filed March 3, 1978).

101. The Supreme Court has recognized constitutional limitations on the scope of the antitrust lavis. For example, solicitation of governmental activity-seeking legislative change through lobbying or seeking executive or administrative agency action-is protected, principally because of the first amendment, even if the result of the sought-after action will harm or even destroy competition. United Mine Workers v. Pennington, 381 U.S. 657 (1965); Eastern R.R. Presidents Conf. v. Noerr Motor Freight, Inc., 365 U.S. 127 (1961).

102. Marjorie Webster Jumior College, Inc. v. Middle States Ass'n of Colleges \& Secondary Schools, Inc., 432 F.2d 650, 653-54 (D.C. Cir.), cert. denied, 400 U.S. 965 (1970); Veizaga v. National Bd. for Respiratory Therapy, 1977-1 Trade Cas. 70,868, 70,869-70 (N.D. Ill. 1977); Jones v. National Collegiate Athletic Ass'n, 392 F. Supp. 295, 296-98 (D. Mass. 1975); Coons, supra note 97.

The Supreme Court cases relied on for this exception are Apex Hosiery Co. v. Leadcr, 310 U.S. 469 (1940), and Klor's, Inc. v. Broadway-Hale Stores, Inc., 359 U.S. 207, 213 n.7 (1959). The premise of those advocating different treatment for non-commercial boycotts 
to deal with the per se rule frontally, rather than through an exception which still leaves within its coverage other forms of neutral, benign, or even competitively beneficial conduct. Non-commercial boycotts should be treated as one of the categories of conduct which one can predict will not always have anticompetitive effects.

2. Effect of the Restraint. In evaluating group boycotts, courts should examine the effect on competition of the challenged conduct, both for its own sake and to evaluate the defendants' purposes and motives. They should go beyond asking whether the refusal to deal arose in a commercial or non-commercial setting, or whether the conduct was motivated by, and had the effect of, coercing or excluding competitors. Rather, the analysis should include the overall effect on competition. There are several situations in which conduct will have some effect on competition, but which should no longer be swept within the per se rule. Two of these situations have already been considered. ${ }^{103}$ Two others are considered here: situations in which a concerted refusal to deal is necessary for efficient operation of the industry, and those in which net economic benefits result.

Concerted refusals to deal in which coordinated conduct by competitors regarding outsiders is essential for the efficient operation of their activities should be dealt with under the rule of reason. For example, an association of professional golfers may determine that a tournament cannot be run with more than a specified number of participants. Through a series of matches, the quahifying golfers are selected; all others are refused entry into the tournament. ${ }^{10 \pm}$ Although the successful qualifiers combine to refuse to compete agaimst the nonqualifiers, and their motive is im part to improve their own economic status, the courts have permitted, and should continue to permit, these refusals to deal. The elimination of competition between the qualifiers and nonqualifiers results in a higher quality of competition among those who do qualify. More important, if the antitrust laws were to require that anyone could play in any tournament, the competition would be chaotic.

This situation is most likely to occur when the parties are engaged in some type of joint venture or where their activities involve some partial integration of roles. ${ }^{105}$ Where the court can determine that the principal motive for adopting these limitations is to promote operational efficiency in the industry, where such efficiency is indeed advanced, and where there is

is that the persons engaged in those kinds of refusals to deal usually are not motivated by an exclusionary purpose, and therefore the conduct would not have a net anticompetitive effect. They also suggest that the legislative intent behind the Sherman Act did not indicate a desire to deal with these non-economic situations. But see Bird, supra note 78, at 275-88, 292 (per se rule should apply even to most non-commercial group boycotts).

103. See notes 91-101 and accompanying text supra.

104. Deesen v. Professional Golfers' Ass'n of America, 358 F.2d 165 (9th Cir.), cert. denied, 385 U.S. 846 (1966). See also Hennessey v. National Collegiate Athletic Ass'n, 564 F.2d 1136 (5th Cir. 1977); Bridge Corp. of America v. American Contract Bridge League, Inc., 428 F.2d 1365 (9th Cir. 1970); cases cited in note 75 supra.

105. Such an argument might have been made in Associated Press v. United States, 326 U.S. 1 (1945). See note 65 supra. 
no satisfactory alternative conduct which would equally achieve those efficiencies, these restraints should not be swept within the per se rule.100

Finally, group boycotts should not be subject to a per se rule if they are noncoercive and nonexclusionary and will help effect net economic benefits. This principle proceeds upon the assumption that activities should never be subject to a per se rule unless courts can be confident that those activities can never produce competitive efficiencies. For example, courts can be sure that no competitive benefit will result froin allowing competitors to tamper with the price-setting mechanisin, because economists have demonstrated that any price other than the one set by market forces, and without. the interference of the defendants' restrictive conduct, is a non-equilibrium, non-market-clearing price. ${ }^{107}$ The saine lack of efficiency is not necessarily characteristic of concerted refusals to deal.

One situation in which a refusal to deal may be procoinpetitive was presented in the Worthen Bank case. ${ }^{108}$ The national BankAmericard system, one of the two nationwide bank credit card organizations, imposed a by-law provision on certain of its bank members prohibiting thein from participating as issuers of credit cards in the Master Charge organization, the other nationwide bank credit card organization. Worthen, a BankAmericard systein member, charged that this by-law resulted in a group boycott by all BankAmericard members of the Master Charge organization. The trial court granted summary judgment for the plaintiff on the ground that no competitive justification could be put forward under the per se doctrine..$^{100}$ The Eighth Circuit reversed. It agreed that the result was to preclude all BankAmericard members subject to the by-law from doing any business with Master Charge, but it recognized significant competitive benefits from the arrangements. Indeed, it was stipulated by the parties that the by-law provision proinoted competition and that absent the boycott it imposed, there would be a diminution of competition between BankAmericard and Master Charge. The court found that the joint action of the BankAmericard systein meinbers promoted efficiency and that the exclusionary practices were necessary to inake this joint venture successful. The Court distinguished the leading group boycott cases and held that on remand the case should be tested by the rule of reason. Such an approach makes sense. Once the defendants' nonexclusionary notive and the net benefits to the public welfare are shown, it would be counterproductive to apply a per se rule. ${ }^{110}$

106. See, e.g., Ackerman-Chillingworth v. Pacific Elec. Contractors Ass'n, 579 F.2d 484 (9th Cir. 1978), cert. denied, 99 S. Ct. 872 (1979); Hatley v. American Quarter Horse Ass'n, 552 F.2d 646, 652-53 (5th Cir. 1977). Accord, Femimist Women's Health Center, Inc. v. Mohammad, 586 F.2d 530, 546-47 (5th Cir. 1978), petition for cert. filed, 47 U.S.L.W. 3761 (May 8, 1979).

107. P. SAMUELSON, ECoNomics 63-68, 397, 516 (10th ed. 1976).

108. Worthen Bank \& Trust Co. v. National BankAmericard Inc., 485 F.2d 119 (8th Cir. 1973), cert. denied, 415 U.S. 918 (1974).

109. Worthen Bank \& Trust Co. v. National BankAmericard Inc., 345 F. Supp. 1309 (E.D. Ark. 1972), rev'd, 485 F.2d 119 (8th Cir. 1973), cert. denied, 415 U.S. 918 (1974).

110. Another example of a concerted refusal to deal mandated by practical business considerations but resulting in economic efficiencies is suggested by Problem 13 in $M$. HANDLER, H. BLAKE, R. PITOFSKY \& H. GoldSCEMMI, supra note 84 , at 523 , and $\Uparrow 375$ in 
Admittedly, this category is potentially large enough to swallow the per se rule, making it meaningless. Unfortunately, it will probably be impossible to define in advance the many varieties of restraints which may fall within it. The Court, however, should expressly recognize the existence of this category and encourage its further explication in the lower courts. With some additional experience, the Court should be able to define this category more specifically.

3. Defendants' Market Power. The defendants' market power is one indicator of the likely impact on competition of any particular restraint. Although there is no readily available method of measuring raw market power, a surrogate frequently used is the percentage of the market controlled by the defendants.111 The resulting figure may be deceptive, because of difficulties in defining the relevant market within which to ascertain the defendants' market sliare, ${ }^{112}$ or because other factors, such as possession of trademarks or relatively high or low capital and technological barriers to entry, may call for a more particularistic examination. In most situations, lowever, it is useful to approximate the defendants' market power. Specifically, two uses can be made of this information. First, it may prove instructive in determining the defendants' purpose or intent in entering into the concerted action and in assessing its likely effect (especially if the plan is not yet fully implemented) so as to determine whether the activities fall within the per se rule. Indeed, in several group boycott decisions the Court lias pointed to the defendants' market sliare as an indication that they intended to coerce the third party, or as evidence of their ability to achieve that

P. AREEDA, supra note 41, at 388. Assume that a group of insurance companies, to cut their overhead and achieve economies of scale, delegates to an evaluation bureau the responsibility of investigation of the background of any applicant for insurance. Although there is no formal agreement to abide by the investigator's recommendation, as a matter of practice, because of their reliance on its superior investigation and evaluation skills, in the past all companies have uniformly refused to issue insurance to any applicant found by the investigator to be an undue risk. It is clear that the net result of this pattern is to deprive an applicant of the benefit of insurance by all the competitors who are inembers of the imvestigation group. Assuming that this conduct could be characterized as a combination or conspiracy-and an inference of an agreement is certainly justifiable, see Theatre Enterprises, Inc. v. Paraniount Film Distrib. Corp., 346 U.S. 537 (1954); Interstate Circuit, Inc. v. Umited States, 306 U.S. 208 (1939) - the conduct would appear to be a concerted refusal by all insurance companies to deal with that applicant. However, not ouly is the effect of the arrangement a great savings in cost-both from economies of scale and from the avoidance of duplicative investigations of risk--but the motivation of the companies in entering the plan was not to coerce the applicant to conform to certain behavior or to drive it out of busimess. There might be some argument that the applicant is entitled to some "due process" safeguards, such as a statement of the reasons for the rejection or an investigation by a second company at the applicant's expense after the negative report by the first evaluator. See Silver v. New York Stock Exch., 373 U.S. 341 (1963); note 135 and accompanying text infra. There is no reason, however, why this conduct should be treated under a per se rule. See also Ruddy Brook Clothes, Inc. v. British \& Foreign Marine Ins. Co., 195 F.2d 86 (7th Cir.), cert. denied, 344 U.S. 816 (1952).

111. See United States v. Grinnell Corp., 384 U.S. 563, 571 (1966); United States v. Socony-Vacuun Oil Co., 310 U.S. 150, $191,223-24$ (1940) (defendants accounted for $83 \%$ of gasoline sales in their areas). See also Continental T.V., Inc. v. GTE Sylvania Inc., 433 U.S. 36, 64 \& n.4, 66 \& n.8 (1977) (White, J., concurring).

112. See, e.g., United States v. E.I. du Pont de Nenuours \& Co., 351 U.S. 377 (1956). 
result. ${ }^{113}$ However, this use of market power is probably less necessary with group boycotts than with some other forms of conduct subject to a per se rule, and seldom will determine the outcome of a case.

It is clear that courts should be more concerned about conduct restraining trade when engaged in by defendants with substantial market shares than by those with relatively trivial market shares. However, with regard to all forms of conduct deemed to be unlawful per se, the argument that the defendants had no market power, and hence could not have had any effect on competition, has been rejected. In view of the substantial reasons described above in favor of per se rules, the courts simply refuse to undertake this analysis.

In contrast, approximation of the defendants' market power is useful in determining the legality of conduct under the rule of reason. The activities of a group of companies which account for a substantial share of a particular market usually will have a larger impact on competition than similar activities by firms with smaller shares. This is particularly true with respect to group boycotts. The effect of a boycott is to foreclose either sources of supply or potential customers to the victin; thus, the greater the market share (and market power) of the defendants, the greater will be the foreclosure of alternatives to the victim and the greater the impact of their refusal to deal on competition.

4. Relationship between the Parties. A number of decisions involving concerted refusals to deal have turned upon the relationship between the boycotting parties; that is, whether the agreenent could be characterized as at least partially horizontal or as solely vertical. This distinction has only limited utility. When considered apart from the purpose and the effect of the agreement, it can lead to undesirable results.

The madequacy of the horizontal-vertical distinction is best illustrated by an examination of four cases with similar factual settimgs-Klor's, Inc. $v$. Broadway-Hale Stores, Inc., ${ }^{114}$ Packard Motor Car Co. v. Webster Motor Car Co., ${ }^{115}$ Oreck Corp. v. Whirlpool Corp., ${ }^{116}$ and Joseph E. Seagram \& Sons v. Hawaiian Oke \& Liquors, Ltd. ${ }^{117}$ In all four cases, a distributor of goods sued its former suppher or suppliers after sales to it had been terminated. In Klor's, the plaintiff alleged that one of its competitors had approached their common suppliers, asking them to discontinue sales to the plaintiff. The Court found that the discussions and agreements resulted in a horizontal conspiracy among the suppliers as well as the vertical conspiracy between them and the competing retailer, and held the conduct unlawful per se. In Packard, the single defendant seller agreed to discontinue sales to the plain-

113. Fashion Originators' Guild of America v. FTC, 312 U.S. 457, 462 (1941); Paramount Famous Lasky Corp. v. United States, 282 U.S. 30, 41 (1930).

114. 359 U.S. 207 (1959).

115. 243 F.2d 418 (D.C. Cir. 1957).

116. 579 F.2d 126 (2d Cir.) (en banc), cert. denied, 439 U.S. 946 (1978), noted in 92 HARV. L. Rev. 1160 (1979).

117. 416 F.2d 71 (9th Cir. 1969), cert. denied, 396 U.S. 1062 (1970). 
tiff after a competing buyer threatened to discontinue purchases from the defendant unless it were named the exclusive distributor for the area. 'Although the result of this threat and the termination of the plaintiff was to drive it out of business and to eliminate all intrabrand competition in the area, the United States Court of Appeals for the District of Columbia Circuit held it reversible error even to let the case go to a jury; instead, a judgment for the defendant was entered.

Two facts help in part to explain the significantly different outcomes of these two cases. Although the Supreme Court opinion in Klor's does not mention the fact, there is some indication that the plaintiff had been cutting prices, and that the termination was an attempt to "discipline" this obviously lawful conduct.118 The conspiracy, if successful, would have diminished both intrabrand and interbrand competition. In Packard, the defendant manufacturer was a small, struggling company facing vigorous interbrand competition. The court may have been persuaded that the only chance for its survival was to have one strong distributor in each geographic area, rather than several weaker ones each atteinpting to take sales away from the other. Although this concerted refusal to deal did eliminate one form of competition (intrabrand), it might have been seen as an attempt to promote another more important form. ${ }^{119}$

In both cases the courts relied too heavily on another distinction-the presence of both a horizontal and a vertical conspiracy among the manufacturers and the competing sellers in Klor's and the solely vertical conspiracy in Packard. Section 1 of the Sherman Act imposes the jurisdictional requirement of plurality of conduct. ${ }^{120}$ In satisfying this requirement, there should be no difference between a coinbination of competitors and a combination of a supplier and a customer. ${ }^{121}$ Both involve two or more persons. The key inquiries instead should be the purpose or intent of the defendants and the effect of the restraint on competition.

In evaluating a number of forms of conduct under section 1 of the Sherman Act, the Supreine Court has emphasized the nature of the relationship between the agreeing parties. The division of territories among competitors, or the allocation of particular customers among competitors-the horizontal restraint-is unlawful per se. ${ }^{122}$ On the other hand, a requirement by a seller that its customers must restrict their resales to certain territories or to specified buyers, and the einbodiment of this requirement in an agree-

118. See Rahl, supra note 33 , at 1172 n.22; Note, Proving Injury to Competition in Private Antitrust Suits Provoked by Concerted Refusals to Deal, 68 YALE L.J. 949, 956 \&. $\mathrm{n} .45$ (1959).

119. This was the Court's rationale in Continental T.V., Inc. v. GTE Slyvania Inc., 433 U.S. 36 (1977), for permitting a manufacturer to impose vertical territorial and customer restraints on its distributors.

120. See note 59 supra.

121. See Albrecht v. Herald Co., 390 U.S. 145, 150 n.6 (1968); United States v. Parke, Davis \& Co., 362 U.S. 29, 45 (1960). See generally Turner, The Definition of Agreement Under the Sherman Act: Conscious Parallelism and Refusals to Deal, 75 HARv. L. REv. 655 (1962).

122. United States v. Topco Assocs., Inc., 405 U.S. 596 (1972). 
ment-the vertical restraint-is dealt with under the rule of reason. ${ }^{123}$ Indeed, in United States v. Sealy, Inc., ${ }^{124}$ which involved claims of unlawful territorial restrictions, the Court identified what has turned out to be the key inquiry:

Because this Court has distinguished between horizontal and vertical territorial limitations for purposes of the impact of the Sherman Act, it is first necessary to determine whether the territorial arrangements here are to be treated as the creature of the licensor, Sealy, or as the product of a horizontal arrangement among the licensees. ${ }^{125}$

Yet, smce the effect of either horizontal or vertical territorial restraint is the elimination of soine forms of competition, the effect of either restramt may be identical. And, when the vertical restraint is imposed by the seller on the buyers at their initiative and behest, the motive and purpose are the same as well.128

Some of the flavor of the horizontal-vertical distinction has also appeared in the Supreme Court's treatment of concerted refusals to deal. Thus, in Klor's the Court poimted out that "[ $\mathrm{t}]$ his is not a case of a single trader refusing to deal with another, nor even of a manufacturer and a dealer agreeing to an exclusive distributorship. Alleged in this complaint is a wide combination consisting of manufacturers, distributors and a retailer."127 Because of this horizontal character, the Court condemncd the restraint. The saine theme appears in later Supreme Court cases as well.123

The lower federal courts have also rehed on this distinction. In Oreck, ${ }^{129}$ the plaintiff was the sole wholesale distributor of defendant Whirlpool's vacuum cleaners; it resold these products by direct mail and to janitorial supply houses. Whirlpool also sold vacuun cleaners to Sears Roebuck, a large retail merchandiser. After the plamtiff's distributorship was terminated, it alleged that Whirlpool had acted in response to requests from Sears, which was disturbed by the plaintiff's pricing policies. The trial resulted in a jury verdict for the plaimtiff, pursuant to the trial judge's instructions that this conduct was covered by the Klor's per se rule. The Second Circuit, einphasizing that any conspiracy here was purcly vertical, held that the conduct should have been tested under the rule of reason. ${ }^{130}$

123. Continental T.V., Inc. v. GTE Sylvania Inc., 433 U.S. 36 (1977).

124. 388 U.S. 350 (1967).

125. Id. at 352. See also Continental T.V., Inc. v. GTE Sylvania Inc., 433 U.S. 36, 58 n.28 (1977).

126. See Pitofsky, supra note 8.

127. 359 U.S. at $212-13$.

128. United States v. Arnold, Schwinn \& Co., 388 U.S. 365, $372-73$ (1967); United States v. General Motors Corp., 384 U.S. 127, 139-40 (1966).

129. Oreck Corp. v. Whirlpool Corp., 579 F.2d 126 (2d Cir.) (en banc), cert. dented, 439 U.S. 946 (1978).

130. 579 F.2d at 131.

Other cases in which a court refused to apply the per se rule to a concerted refusal to deal because the relationship between the parties was vertical include Harold Friedman, Inc. 
Since one objection to group boycotts is the undesirability of the use of joint market power by competitors-quite apart from any effect on coinpetition froin the cooperation-it is understandable that courts have dealt more harshly with horizontal restraints. Yet Oreck indicates the problein that may occur when the distinction becomes a key element. of the operating rule and the court fails to examine adequately the defendants' purpose in entering into the combination or the effect of restraint. If it could have been shown that the manufacturers in Klor's joined in refusing to sell to the plaintiff not because they wanted to achieve the anticompetitive purpose of enforcing resale price maintenance, but for some procompetitive or societally beneficial reason, it would have been inappropriate to.condemn the restraint as unlawful per se. Similarly, if the favored distributor in Packard v. Webster had objected to the cut-off dealer not because they were both relatively small, but because the dealer was engaging in price-cutting and the termination was an effort to discipline it, ${ }^{131}$ or because the favored distributor wanted a inonopoly in a thriving market, ${ }^{132}$ the court should not have directed a verdict for the defendant. To the contrary, application of the per se rule in that situation would seem quite appropriate. The Oreck court slighted these considerations by overemphasizing the vertical nature of the conspiracy. ${ }^{133}$

In fact, recognition of the importance of other distinctions has appeared in some lower court decisions. In the Hawaiian Oke case, the plaintiff was the former distributor of the goods of two of the defendants. It alleged that, pursuant to a request from the third defendant, the two suppliers had agreed simultaneously to terminate the plaintiff's distributorship and to appoint the third defendant as the new distributor. The supplier-defendants

v. Thorofare Markets, Inc., 587 F.2d 127, 142 n.57 (3d Cir. 1978); Mutual Fund Investors, Inc. v. Putnam Management Co., 553 F.2d 620, 626 (9th Cir. 1977); and Gough v. Rossmoor Corp., 585 F.2d 381, 386-87 (9th Cir. 1978), cert. denied, 99 S. Ct. 1280 (1979). See also Sitkin Smelting \& Ref. Co. v. FMC Corp., 575 F.2d 440, 446-47 (3d Cir.), cert. denied, 439 U.S. 866 (1978).

131. See Miami Parts \& Spring, Inc. v. Champion Spark Plug Co., 364 F.2d 957, 968 (5th Cir. 1966).

132. See Six Twenty-Nine Prods., Inc. v. Rollins Telecasting, Inc., 365 F.2d 478, 484-85 (5th Cir. 1966).

133. Upon remand in Oreck, the key issue should be defendant's intent in terminating plaintiff as a distributor. The district court's instructions had stated that proof merely of a conspiracy between the seller and the favored distributor sufficed for finding a per se violation. 579 F.2d at 129, 137-38 (Mansfield, J., dissenting). Although it is true that the plaintiff alleged and introduced evidence of the favored distributor's wish to terminate plaintiff because of its price-cutting activities, the defendant offered evidence that the plaintiff was an ineffective and unresponsive dealer and was terminated for that reason. In view of this conflict, the district court's per se approach was too broad; the instructions erroneously deprived the jury of the opportunity to evaluate the actual motives of the defendants.

The Second Circuit in Oreck concluded that the "agreement becomes violative of $\S 1$ of the Sherman Act only if it is anticompetitive in purpose or effect-in sum, it must be tested by the rule of reason." Id. at 133 (emphasis in original). However, the court reached this conclusion only after characterizing the conduct as strictly vertical, and stressing the importance of this characterization. The purpose and effect of the restraint should be critical, regardless of whether the relationship of the parties is at least partially horizontal or is purely vertical. There may well be situations-such as terminations to discipline a pricecutter-which are purely vertical but are nonetheless appropriate for per se treatment. 
argued that their decisions were made independently, but the court's opinion proceeded on the assumption that there indeed was a joint understanding to terminate the plaintiff. Nonetheless, the court held that this horizontal conspiracy did not constitute a group boycott unlawful per se under the Sherman Act. The sellers had apparently become dissatisfied with the plaintiff's performance, and had resolved to appoint another distributor. As a matter of sound business practice, a successful distributor needed to carry the lines of more than one manufacturer. By acting jointly to appoint the new distributor, defendants were not seeking to coerce the plaintiff to conform to certain business practices, nor was it their intention to drive it out of business. Rather, they were motivated by a legitimate business interest in seeing that their new distributor was successful. A rule that a single seller could never agree with another company, such as the prospective new customer, to change distributors is contrary to business necessities. The court in Hawaiian Oke recognized that a horizontal agreenent with a competitor to change distributors simultaneously, when motivated by the same business necessities, should not become illegal merely because the competitors are acting cooperatively. ${ }^{134}$

In short, an examination of the facts of these cases indicates that mere labeling cannot be enough. The Court cannot simply rely on a determination of whether at least two competitors, either acting alone or in conspiracy with their seller, have agreed to refuse to do business with another trader. The inquiry must go beyond this characterization to a look at the nature, history, purpose, and effect of the restraint.

5. Other Considerations. Finally, after forging a rule which will bring some concerted refusals to deal back within the rule of reason, the Court should consider some additional elements. Under the rule of reason, the Court should first insist upon a showing that there were no less restrictive alternatives which could have achieved the same procompetitive effects from the concerted activity. In addition, it should insist that the object of the restraint be accorded some opportunity to demonstrate that the proposed restraint is unfair or inappropriate. In Silver, ${ }^{135}$ for example, the Court held that the refusal, without more, of the members of the New York Stock Exchange to deal with plaintiff would be an illegal group boycott. The Court noted that the cut-off would have been permissible if the facts showed the plaintiff had not met the minimum qualifications for a securities dealer. However, the Sherman Act required that, before the defendants could engage in this concerted refusal to deal, the plaintiff be afforded procedural safe-

134. 416 F.2d at 74-80.

There have been numerous challenges under the antitrust laws, principally under a concerted refusal to deal theory, by terminated dealers against their former suppliers. In addition to the cases discussed in the text, see, e.g., Mutual Fund Investors, Inc. v. Putnam Management Co., 553 F.2d 620, 626 (9th Cir. 1977); Bowen v. New York News, Inc., 522 F.2d 1242, 1253-57 (2d Cir. 1975), cert. denied, 425 U.S. 936 (1976); Bushie v. Stenocord Corp., 460 F.2d 116, 119-20 (9th Cir. 1972); Miami Parts \& Spring, Inc. v. Champion Spark Plug Co., 364 F.2d 957 (5th Cir. 1966).

135. Silver v. New York Stock Exch., 373 U.S. 341 (1963). 
guards. The Deesen case ${ }^{136}$ suggests a similar approach - before the plaintiff was suspended from the professional golf circuit, he was afforded an opportunity to show that his golf skills had not deteriorated. Explicit imposition by the Court of a requirement of fair and reasonable dealing with the affected third party would not only help show that the defendants did not have an exclusionary or coercive intent in refusing to deal; it would also be evidence that no less restrictive alternative was available to achieve the procompetitive effects of the restraint.

\section{CONCLUSION}

The present rule making concerted refusals to deal unlawful per se was adopted without sufficient examination of the possible justifications for that conduct. The utility of the rule is compromised by the lack of adequate definition of the conduct subject to the rule. The principal focuses today are on the existence of plurality of conduct; finding some horizontal component to that agreement; noting whether the activity arose in a commercial or non-commercial setting; and occasionally allowing some imquiry into the motives for and the effects of the conduct to come in through the back door as possible justifications. The rule should be restructured to make the motivations for, and the effect of, the restraint the principal inquiry. This would be done by first defining concerted refusals to deal broadly, as any agreement by two or more persons in any competitive relationship with each other-horizontal, vertical, or otherwise-in which they refuse to deal with third parties for whatever reason. The Court should then articulate the situations in which these concerted refusals to deal might have anticompetitive effects. Those which are suspected almost always to have those effects can be brought within a new, and more specifically defined, per se rule. The rule should be drawn so as always to deem unlawful those group boycotts where the parties intended to coerce or exclude another in order to lessen or eliminate some form of competition. Other situations, which might frequently be justified, should be dealt with forthrightly under a rule of reason. The present situation, which permits the inquiry through purported exceptions from an apparently rigid Supreme Court rule, only results in confusion and disregard for sound jurisprudence. ${ }^{137}$

136. Deesen v. Professional Golfers' Ass'n of America, 358 F.2d 165 (9th Cir.), cert. denied, 385 U.S. 846 (1966); see text accompanying note 104 supra.

137. For a fascinating example of a court's attempt to avoid the perceived harshness of the per se approach, see Cullum Elec. \& Mechamical, Inc. v. Mechanical Contractors Ass'n, 436 F. Supp. 418, 428-30 (D.S.C. 1976) (association rule requiring subcontractors to submit bids to general contractors at least five hours before time to open general bids is reasonable and noncoercive; subcontractor whose lower bid, offered within five-hour period, was rejected, fails to state cause of action for concerted refusal to deal). 